\title{
Belgium: Technical Note on Financial Conglomerate Supervision
}

This paper was prepared based on the information available at the time it was completed on May 16, 2013. The views expressed in this document are those of the staff team and do not necessarily reflect the views of the government of Belgium or the Executive Board of the IMF.

The policy of publication of staff reports and other documents by the IMF allows for the deletion of market-sensitive information.

Copies of this report are available to the public from

International Monetary Fund • Publication Services

700 19th Street, N.W. • Washington, D.C. 20431

Telephone: (202) 623-7430 • Telefax: (202) 623-7201

E-mail: publications@imf.org • Internet: http://www.imf.org

\section{International Monetary Fund Washington, D.C.}




\title{
INTERNATIONAL MONETARY FUND
}

\section{BELGIUM}

\section{FINANCIAL SECTOR ASSESSMENT PROGRAM UPDATE- TECHNICAL NOTE-FINANCIAL CONGLOMERATES SUPERVISION}

\section{EXECUTIVE SUMMARY}

\begin{abstract}
Before the crisis, Belgian financial conglomerates (FCs) were been important players both domestically and internationally. Similar to other European peers, Belgian FCs developed as large and complex financial groups with business activities combining banking and insurance ("bancassurance model"), taking advantage of important synergies in terms of marketing and distribution channels. The Belgian FCs engaged in a rapid expansion, fueled by significant leveraging, which enabled them to occupy a dominant position domestically (over 80 percent of the financial market's assets), while some groups (Dexia, Fortis) became top international players internationally. The tremendous growth of the Belgian FCs led nevertheless to a buildup of risks far outpacing internal risk management and supervisory capabilities at the time.
\end{abstract}

The global financial crisis hit the largest Belgian FCs hard-all had to be intervened and all but one substantially restructured. At the onset of the crisis, the largest Belgian FCs were heavily reliant on wholesale funding and had significant portfolios of structured assets. The closure of the wholesale and securitization markets led to a sharp deterioration in conditions, which eventually required massive state support and, in some cases, intervention by the Belgian and other EU states. Substantial losses, deep restructuring, and mandatory deleveraging triggered a reduction of the domestic market share for the four remaining FCs to 50 percent of the financial sector's assets at present and the cross-border activities shrank considerably. The bancassurance model remains important in generating synergies in terms of marketing, distribution, and risk management, but also poses challenges for supervision and systemic risk that need to be tackled.

The Belgium regulatory regime for conglomerates draws from the European Union (EU) framework, which has a number of weaknesses. The various EU directives applicable to financial entities part of a conglomerate create a number of regulatory loopholes. For example, there is room for regulatory arbitrage between the banking and insurance regimes, the supervisory toolbox is limited for mixed financial holding 
companies (MFHCs), and prudential requirements at the group level (i.e., in the areas of group-wide capital planning or liquidity) are incomplete.

Some of these gaps should be addressed through the ongoing EU-wide process of revising the relevant directives. A recent amendment of the EU Financial Conglomerates Directive (FICOD 1), addresses some of the unintended consequences of the initial text, by materially improving supervisory powers at the MFHC level. Therefore, unintended consequences of the original FICOD, causing gaps in the supervision of FCs headed by a holding structure, will be corrected and will ensure a supervisory framework on top of the sectoral group regimes. Planned changes to EU-level supervisory institutions (i.e., the proposed Banking Union) will also have an important impact on the way in which FCs will be supervised in Belgium, with most banks likely to fall under the European Central Bank (ECB) oversight, while insurance companies will continue to be supervised by the NBB.

The NBB's supervisory choices within EU-wide constraints have been prudent and pragmatic in applying the most comprehensive regulatory regime to its most important conglomerates, but resulted in a fragmented operational framework. The NBB and its supervisory predecessor the Commission Bancaire, Financière et des Assurances (CBFA) chose to apply the stricter regulatory regimes allowed under the EU directives by exercising "waivers" for some FCs to preserve greater powers under the sectoral banking legislation. This has resulted in a differentiated supervisory treatment for: a) FCs which fall under the sectoral banking supervision (in particular financial holding companies-FHCs), where the powers and tools are stronger, and b) FCs that remain under specific conglomerate supervision (MFHCs), where the supervisory framework is generally weaker. In some cases, additional supervisory reporting has been required.

Belgium needs to better articulate its supervisory approach for FCs. Individualized supervisory strategies may hide potential conflicts of interests, risks of contagion, and misguide the overall measurement of aggregated risks that very often arise in FCs with multiple sectors of business. A more comprehensive supervisory approach for FCs is therefore needed, including enhanced powers for NBB and sharpened tools and processes to better capture conglomerate-specific risks.

First, supervisory powers over MFHCs need to be considerably enhanced. In particular, the NBB should have the formal power to require the introduction of a comprehensive capital planning process at the level of the MFHC, including forwardlooking stress tests. Furthermore, liquidity should be monitored across all FCs (including MFHCs) and the NBB should have the power to impose sound governance principles over non-regulated entities which head the conglomerates. To meet this recommendation, the NBB should expedite the implementation of the revision of the FICOD. Forthcoming work at the level of the European Sub-Committee on Financial 
Conglomerates should also provide further guidance on developing supervisory practices across sectors.

Second, the existing supervisory tools for monitoring conglomerate-specific risks need to be enhanced in both depth and scope. The NBB should consider applying more conservative solvency tests to determine the true loss absorbency of the parent company; monitor multiple leveraging of capital within FCs; introduce reporting of group-wide risk concentrations; and consider setting limits on intra-group risks and transactions. The existing requirements for corporate governance need to be more consistently applied across FCs. A clearer and more uniform application of prudential requirements will naturally lead to the development of a supervisory baseline for FCs.

Third, the NBB is encouraged to continue its efforts to improve the offsite and onsite supervisory processes across sectors. In particular, the efforts to improve the risk scorecards for the insurance and the securities sectors would enable a higher level of intensity and more consistent assessment of risks across sectors. Furthermore, the overall assessment of the internal control and risk management would be enhanced through a better articulation of the supervisory processes, such as the internal capital adequacy assessment reports by the group, more frequent onsite reviews, and discussions with the board and management, as well as with internal and external auditors. Domestic supervisory cooperation across financial sectors should also be framed in a formalized accord between FSMA and NBB.

\section{Such advancements would facilitate more effective monitoring of cross-sectoral risks and enable horizontal comparisons across the sector. While the current population of conglomerates is limited, the discipline of having a peer group for comparison may contribute in informing the supervisor's assessment not only of institutions or groups, but of the market segment. The NBB is well positioned to carry- out this work by it technical ability to blend the macro- and micro- aspects impacting the FCs within the cross-sectoral multi-disciplinary internal committees.}

Detailed Policy recommendations are shown in Table 1. 
Table 1. Detailed Policy Recommendations

\begin{tabular}{|c|c|}
\hline Recommendations & Priority \\
\hline \multicolumn{2}{|l|}{ Supervisory Powers and Authority } \\
\hline Enhance supervisory powers over a mixed financial holding company (MFHC). & $\begin{array}{l}\text { High, depends on EU- } \\
\text { wide changes }\end{array}$ \\
\hline \multicolumn{2}{|l|}{ Supervisory Responsibility and Coordination } \\
\hline $\begin{array}{l}\text { Formalize supervisory coordination and communication between NBB and FSMA to } \\
\text { enhance group-wide supervision in the new supervisory structure. }{ }^{1}\end{array}$ & High \\
\hline $\begin{array}{l}\text { Establish a conglomerate supervisory baseline through formalization of supervisory } \\
\text { processes and validation enabling NBB to benchmark to international standards. }\end{array}$ & High \\
\hline $\begin{array}{l}\text { Formalize and strengthen supervisory processes to evaluate internal control and risk } \\
\text { management assessments. }\end{array}$ & Medium \\
\hline \multicolumn{2}{|l|}{ Governance } \\
\hline $\begin{array}{l}\text { Conduct a higher level of validation and back testing to ensure the accuracy of the } \\
\text { self-reporting in the area of governance of FCs. }\end{array}$ & Medium \\
\hline Apply governance requirements consistently across financial conglomerates. & High \\
\hline \multicolumn{2}{|l|}{ Risk Management } \\
\hline $\begin{array}{l}\text { Introduce reporting of group-wide risk concentrations and consider setting limits on } \\
\text { intra-group risks and transactions for all FCs. }\end{array}$ & $\begin{array}{l}\text { Medium, depends on } \\
\text { EU-wide changes }\end{array}$ \\
\hline $\begin{array}{l}\text { Make consistent use of scorecards across all sectors upon finalization of insurance and } \\
\text { securities scorecarding systems. }\end{array}$ & High \\
\hline Implement and embed multi-sectoral stress testing for FCs. & Medium \\
\hline $\begin{array}{l}\text { Develop a macro analytical approach for analyzing conglomerates, including by } \\
\text { building peer group analysis capabilities. }\end{array}$ & Medium \\
\hline \multicolumn{2}{|l|}{ Capital and Liquidity } \\
\hline $\begin{array}{l}\text { Develop a supervisory approach to detect double and multiple gearing of capital and } \\
\text { multiple leveraging within FCs. }\end{array}$ & High \\
\hline Enhance the ability to assess liquidity at the group level for all FCs. & $\begin{array}{l}\text { Medium, depends on } \\
\text { EU-wide changes }\end{array}$ \\
\hline Enhance the ability to request a group-wide capital planning process for all FCs. & $\begin{array}{c}\text { Medium, depends on } \\
\text { EU-wide changes }\end{array}$ \\
\hline
\end{tabular}


Approved By Christopher Towe
Prepared by Alexandria Luk (external expert, US Office of the Comptroller of the Currency) and Oana Nedelescu (MCM)

\section{CONTENTS}

GLOSSARY

INTRODUCTION

THE BELGIAN BANCASSURANCE MODEL-SYNERGIES AND VULNERABILITIES 8

ANALYSIS OF THE BELGIAN SUPERVISORY FRAMEWORK FOR FINANCIAL

A. Supervisory Powers and Authority ___ 11

B. Supervisory Responsibility___ 16

C. Corporate Governance __ 17

D. Risk Management__ 19

E. Capital _ 22

CONCLUSIONS AND RECOMMENDATIONS__ 27

\section{BOXES}

1. The International Framework for Conglomerate Supervision___ 12

2. The Requirements for FCs Risk Management___ 19

3. Capital Adequacy Tests Applied by NBB at the Conglomerate Level __ 24

\section{TABLES}

1. Detailed Policy Recommendations 4

2. Comparative Characteristics of a Conglomerate's Business Areas___ 10

3. Differentiated Prudential Treatment Under FICOD and Sectoral Directives___ 15

4. Prudential Treatment of Participations in the EU __ 26

\section{APPENDIX}

I. Group Requirements-Mapping European and Belgium Directives with 2012 Joint Forum Principles 29 


\section{Glossary}

$\begin{array}{ll}\text { ALM } & \text { Asset Liability Management } \\ \text { BCBS } & \text { Basel Committee on Banking Supervision } \\ \text { BCPs } & \text { Basel Core Principles for Effective Banking Supervision } \\ \text { CBFA } & \text { Commission Bancaire, Financière et des Assurances } \\ \text { CRD } & \text { Capital Requirements Directive } \\ \text { D-SIFI } & \text { Domestic Systemically Important Financial Institutions } \\ \text { EBA } & \text { European Banking Authority } \\ \text { ECB } & \text { European Central Bank } \\ \text { EEA } & \text { European Economic Area } \\ \text { EIOPA } & \text { European Insurance and Occupational Pensions Authority } \\ \text { ESMA } & \text { European Securities and Markets Authority } \\ \text { FSB } & \text { Financial Stability Board } \\ \text { FSMA } & \text { Financial Services and Markets Authority } \\ \text { EC } & \text { European Commission } \\ \text { EU } & \text { The European Union } \\ \text { FC } & \text { Financial Conglomerates } \\ \text { FHC } & \text { Financial Holding Company } \\ \text { FICOD } & \text { FC Directive } \\ \text { IAIS } & \text { International Association Insurance Supervisors } \\ \text { ICPs } & \text { Insurance Core Principles } \\ \text { ICAAP } & \text { Internal Capital Adequacy Assessment Process } \\ \text { IOSCO } & \text { International Organization of Securities Commissions } \\ \text { Joint Committee } & \text { Joint Committee of the European Supervisory Authority } \\ \text { MFC } & \text { Macro-Financial Committee } \\ \text { MFHC } & \text { Mixed Financial Holding Company } \\ \text { MiFID } & \text { Markets in Financial Instruments Directive } \\ \text { NBB } & \text { National Bank of Belgium } \\ \text { RC } & \text { Risk Committee } \\ \text { SIFI } & \text { Systemically Important Financial Institutions } \\ \text { SREP } & \text { Supervisory Review and Evaluation Process } \\ & \end{array}$




\section{INTRODUCTION ${ }^{1}$}

1. This report reviews the financial conglomerates (FCs) supervisory framework in Belgium and identifies policy recommendations to address risks and associated vulnerabilities. The note uses the Joint Forum (JF) Principles for the Supervision of Financial Conglomerates ${ }^{2}$ released in September 2012 as a guidance to review significant components of a conglomerate supervisory regime and to benchmark NBB's supervisory framework against internationally accepted principles. The note is not intended to be a formal assessment of compliance with the aforementioned principles.

\section{FCs are defined as complex groups operating in multiple streams of the financial} sector, most frequently in banking and insurance. The FCs pose specific risk management and supervisory challenges due to their complexity in organizational structures, activities, and risks. Within the EU, the combination of banking and insurance activities within the same group is commonly known as the "bancassurance" model. Prior to the global financial crisis, the Belgian bancassurance conglomerates controlled over 80 percent of the Belgian financial market (deposits, assets, and loans) and had significant cross-border operations.

\section{Despite significant restructuring following the crisis, FCs remain important players in} the Belgian financial sector. Against the backdrop of the crisis the three largest Belgium bancassurance groups, Fortis, Dexia, and KBC required significant state intervention and restructuring. Fortis and Dexia Group were split along national lines and dismantled, while KBC engaged in a comprehensive divestment plan. At present, there are four major bancassurance groups in Belgium are: (1) KBC; (2) Belfius (formerly Dexia Bank Belgium); (3) Argenta; and (4) AXA. These four groups have a presence in retail banking, insurance, corporate banking, asset management and other financial market activities in Belgium, controlling collectively over 50 percent of all banking and insurance sector assets. KBC also continues to have significant cross-border operations.

\section{Further transformations in the Belgian bancassurance model and supervisory} structures and processes may occur in the future. The reorientation of the Belgian financial institutions towards the domestic market will increase competition and put pressure on the Belgian FCs to generally rethink their business models. On the other hand, Belgian FCs will be affected by pending regulatory and institutional changes in the EU framework. In particular, the ECB is to become the supervisor of most of the banks which are now part of FCs, while insurance companies in the same group will continue to be supervised by the NBB. With NBB continuing to be substantially involved in both the transition and steady state phases of the Banking Union, strong supervisory vigilance are warranted.

\footnotetext{
${ }^{1}$ Prepared by Alexandria Luk (external expert, US Office of the Comptroller of the Currency) and Oana Nedelescu (MCM).

${ }^{2}$ See http://www.bis.org/press/p120924.htm.
} 


\section{THE BELGIAN BANCASSURANCE MODEL-SYNERGIES AND VULNERABILITIES}

5. The bancassurance model provides important synergies in terms of marketing, distribution, and risk management. The business model started expanding in Belgium in the nineties, when financial entities began combining products from multiple sectors to take advantage of efficiencies in distribution and marketing. The process led to mergers and acquisitions which resulted in a few competitive giants with extensive networks (Fortis, Dexia, KBC). 'One-stop shopping' provided customers with a variety of financial products, ranging from mortgages to fire and life insurance. For insurance companies the model offered new distribution channels ${ }^{3}$ with a stable customer base, while banks were able diversify products and enhance profitability by selling more products utlizing the same 'bricks and mortar' already in place and minimizing operating costs.

6. The bancassurance model poses specific supervisory challenges and may raise systemic concerns. The typical risks associated with conglomerates include increased complexity in terms of size, organization, and activities, insufficient assessment of cross-sectoral risks and contagion, and potential conflicts of interest between sectors - what may be good for the bank may not be for the insurer. The large size of many financial conglomerates and their interconnectedness with other financial institutions and markets, both retail and wholesale, domestically and internationally can also raise 'too big to fail concerns', as proven by the need for massive state interventions during the financial crisis.

\section{The first dimension of complexity in FCs relates to their complex organizational} structures, which can be difficult to supervise. Financial conglomerates can either be organized around unregulated holding companies which hold participations in insurance and banking entities (i.e., KBC Group, AXA, Argenta), or in groups of companies which do not necessarily have a top level holding company (i.e., Belfius, in which the insurance arm is established as a subsidiary of the bank). Adding to the complexity of the legal structure is the large number of entities forming the conglomerate, both regulated and unregulated, operating domestically or cross-border.

\footnotetext{
${ }^{3}$ According to the ICP Assessment, about one third of the insurance business is carried out through bank employees who sell products of the same financial group.
} 


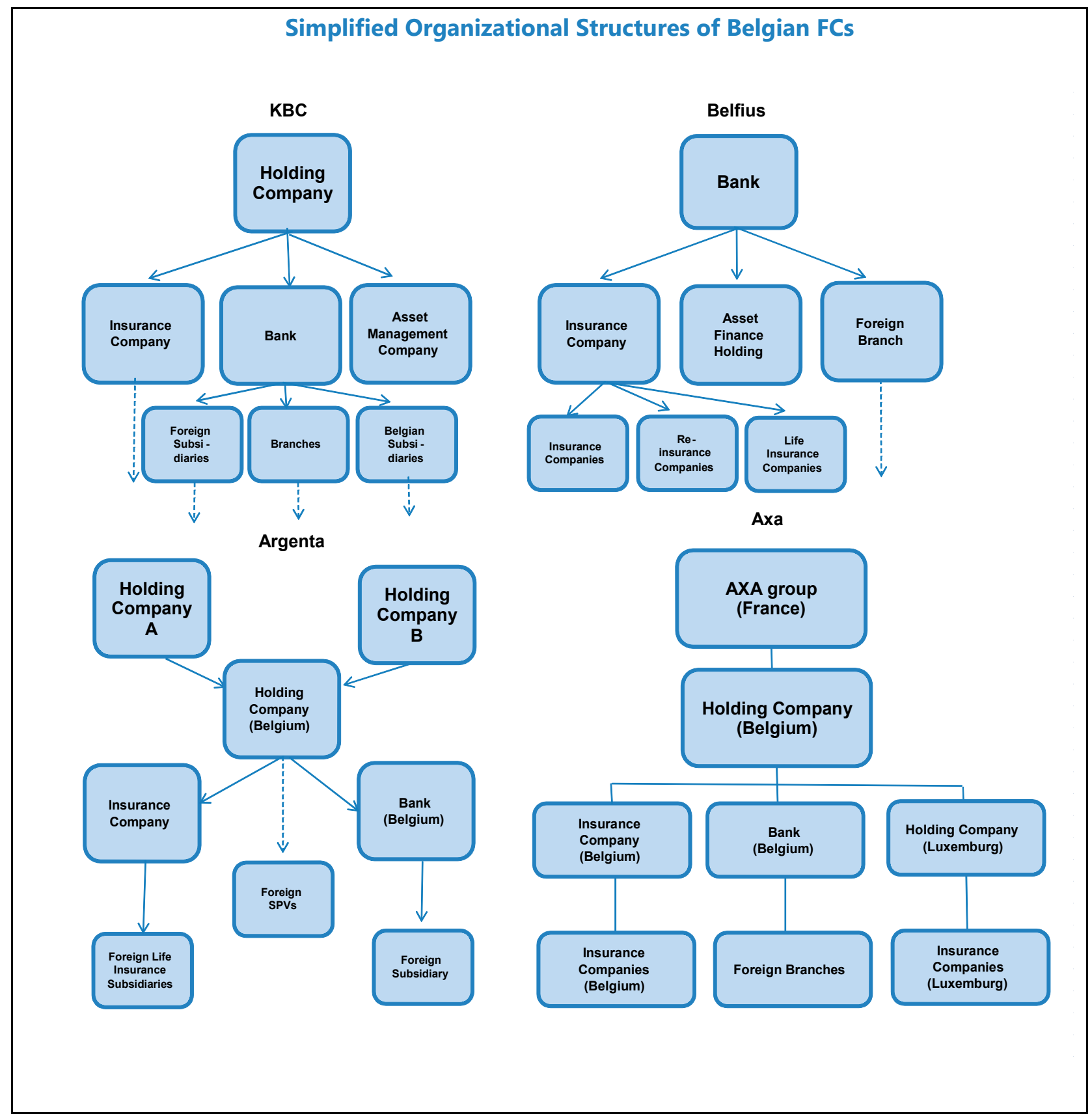

\section{Besides regulated activities, conglomerate structures can also include shadow banking} activities, which can further increase risks. Before the crisis, the Belgium BCs were highly active in many of the shadow banking activities. On the backdrop of poor group-wide risk management and insufficient supervision such activities inflicted significant losses. ${ }^{4}$ Fortis incurred losses of $€ 4.8$ billion in 2008 on its structured credit portfolio (mainly composed of ABS and CDOs). Dexia incurred losses

\footnotetext{
${ }^{4}$ See NBB Financial Stability Review, 2012 for a description of involvement of the Belgian financial conglomerates in shadow banking activities before the crisis.
} 
of €3.2 billion associated with its subsidiary Financial Security Assurance which provided credit insurance and held a large portfolio of securitized products. Finally, KBC acted as an originator of securitized products, mainly CDOs, through its KBC Financial Products and invested heavily in securitized products, which triggered losses of $€ 6.1$ billion in 2008 and 2009.

\section{Second, the cross-sectoral nature of the bancassurance model poses risk management} and supervisory challenges. Product characteristics and risk behavior of similar bank and insurance products are quite different (Table 2). Therefore, blending banks and insurers and their risks can increase opacity and overwhelm both business managers and supervisors. Furthermore, as outlined below (Section E), the application of sectoral rules can open the door for regulatory arbitrage between banks and insurance companies, of which FCs can take advantage.

Table 2. Comparative Characteristics of a Conglomerate's Business Areas

\begin{tabular}{|c|c|c|}
\hline Type of entity & Bank & Insurance \\
\hline Assets & $\begin{array}{l}\text { Customer loans, securities, } \\
\text { interbank assets }\end{array}$ & Investment portfolio \\
\hline Liabilities & $\begin{array}{l}\text { Customer deposits, interbank } \\
\text { liabilities }\end{array}$ & Technical provisions \\
\hline $\begin{array}{l}\text { Business time } \\
\text { horizon }\end{array}$ & Intermediate & $\begin{array}{l}\text { Long (life), long or short (non } \\
\text { life) }\end{array}$ \\
\hline Main risks & Credit risk, liquidity risk & $\begin{array}{l}\text { Underwriting risk, investment } \\
\text { risk, interest rate risk }\end{array}$ \\
\hline $\begin{array}{l}\text { Main risk transfer } \\
\text { mechanisms }\end{array}$ & $\begin{array}{l}\text { Securitization, credit } \\
\text { derivatives, OTC derivatives }\end{array}$ & Reinsurance \\
\hline
\end{tabular}

10. Third, the decision making process in FCs is not immune from a risk of conflicts of interest. Banking and insurance arms may be unequally affected by some group decisions, for example when the insurer is required to sell off a profitable business and transfer liquidity to the parent, a situation that could lead to a deterioration of the profitability of the insurer but that may support the liquidity of the bank. Common management across entities of the group may also be a source of conflicts of interest and weaken the overall governance and risk management of an FC.

11. Finally, interconnectedness among group entities through ownership participations, intra-group transactions, and management processes increases supervisory challenges. The multiple use of capital - 'multiple gearing' (where capital is used twice or more within a conglomerate) or 'multiple leveraging' (where a parent company issues debt and downstreams the proceeds as an equity investment in its subsidiaries) can weaken the overall capitalization of a FC. Furthermore, intra-group operations or operations with the same clients or group of connected clients may increase concentration risks. The multifaceted complexities and risks of FCs justify the development of a strong supervisory framework for conglomerate supervision. 


\section{ANALYSIS OF THE BELGIAN SUPERVISORY FRAMEWORK FOR FINANCIAL CONGLOMERATES}

\section{A. Supervisory Powers and Authority}

\section{The supervision of FCs complements the prudential supervision of the individual}

sectors. The FCs supervisory layer adds to the solo and consolidated sectoral supervision group and cross-sectoral supervisory elements ${ }^{5}$. In particular, conglomerate supervision should detect and monitor specific group risks such as the double gearing of capital, risks of contagion, management of complexity, concentration, and conflicts of interest, which rise incrementally when licenses for different financial services are combined under the same umbrella. The biggest challenge in articulating a workable framework for FC supervision is to capture the complexity of structures, activities and risks in conglomerates, while avoiding unnecessary duplication with sectoral prudential standards.

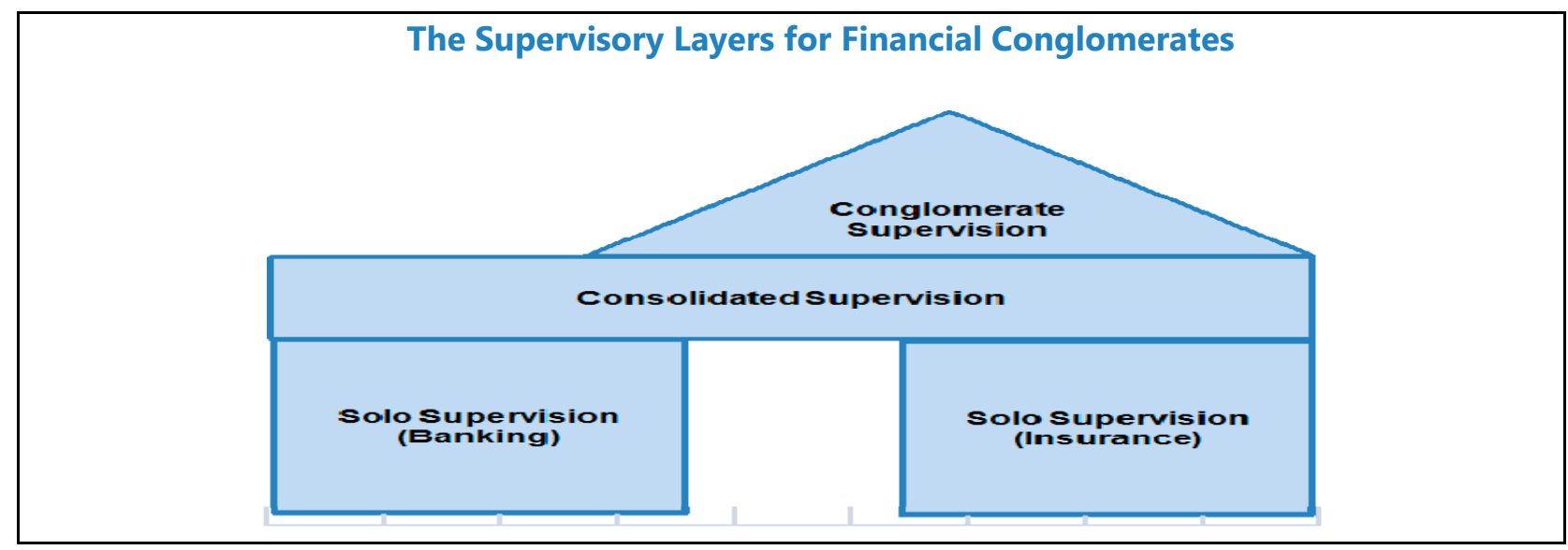

13. The international and EU regulatory frameworks for the supervision of FCs have evolved as a result of the financial crisis. Following the outbreak of the financial crisis, the principles for the supervision of FCs were updated to enhance focus on activities and risk at the group level and for unregulated entities. The supplemental conglomerate supervision framework, as outlined in the JF Principles for the Supervision of FCs, was updated in 2012 to further support the reach and effectiveness of conglomerate supervision ${ }^{6}$. Within the EU, the first European Directive

\footnotetext{
${ }^{5}$ As outlined in the core principles for BCBS, IAIS, and IOSCO. More recently, the sectoral core principles have been updated by the parent bodies with IAIS and BCBS issuing new ICPs and BCPs in 2011 and 2012, respectively.

${ }^{6}$ The JF comprises a group of financial sector supervisors working under the aegis of its parent committees: the Basel Committee on Banking Supervision, the International Organization of Securities Commissions and the International Association of Insurance Supervisors ('the Parent Committees'). The objective of the JF is to support banking, insurance and securities supervisors in meeting their regulatory and supervisory objectives and, more broadly, to contribute to the international regulatory agenda in particular where risks exist across or in gaps between the three supervised sectors.
} 
regulating FCs (Directive 2002/87/EC on the supplementary supervision of credit institutions, insurance undertakings and investment firms in a financial conglomerate - FICOD) introduced in 2002, was updated in 2011 (FICOD 1), while further improvements are currently considered (Box 1).

\section{Box 1. The International Framework for Conglomerate Supervision}

The original concepts of conglomerate supervision originated with the $1999 \mathrm{JF}$ Principles for the Supervision of FCs. The JF framework on conglomerates supervision provided guidance in a number of essential areas:

- $\quad$ capital measurement and adequacy at the conglomerate level;

- $\quad$ sound and prudent management of the entities within a financial conglomerate;

- information sharing between supervisors or regulated entities belonging to internationally active financial conglomerates; and

- $\quad$ supervisory guidance for the identification of a coordinator and a set of elements of coordination in emergency and non-emergency situations.

- $\quad$ The JF principles were updated in 2012 to provide guidance for:

- $\quad$ enhanced powers, authority and resources to perform FC supervision; and

- increased requirements for robust governance, capital, liquidity, and risk management frameworks.

The 1999 principles were transposed at the European Union level in the Directive 2002/87/EC of the European Parliament and of the Council of 16 December 2002 (FICOD), which introduced group-wide supplementary supervision. FICOD provided the legal basis to exercise prudential supervision of groups that are active in two or more financial sectors. The directive was updated in 2011 (FICOD1) to provide for enhanced supervisory powers, the inclusion of hedge funds and asset management companies into the framework for supplementary supervision, and increased transparency requirements. A more fundamental revision of FICOD (FICOD 2) may be considered going forward.

Sources: JF Principles, European Commission (EC), and NBB.

14. The Belgian framework for the supervision of risks in FCs derives from a complex legislative set which transposes the EU relevant Directives. The NBB is the supervisory authority charged with the supervision of banks and insurance companies, as well as of FCs more broadly. Since 2011, the NBB's supervisory powers and authority over the entities which are part of FCs draw from three main blocks of legislation:

- sectoral legislation, consisting of banking and insurance laws (mainly the Banking Law of 22 March 1993 and the Insurance Law of 9 July 1975, and the NBB Organic Law of 22 February of 1998, all subsequently amended and closely aligned to the EU sectoral Directives on banking and insurance); 
- specific FC legislation, as governed by the 2005 Financial Conglomerates Royal Decree, which formalized the technical aspects comprised in FICOD for the FC's identification and supervision; ${ }^{7}$

- framework for the domestic systemically important financial institutions (D-SIFIs), drawing from the 2011 amendments of the NBB Organic Law, outlining supplementary requirements and powers for financial entities qualifying as D-SIFIs.

15. The NBB has the authority to designate FCs. The Belgian legislation empowers the NBB to use a number of qualitative and quantitative criteria (Art. 49 bis of the Banking Law) to identify financial conglomerates:

- in the case an unregulated holding company is at the top of the group, the activities of the group must be "mainly" in the financial sector (i.e., the ratio of the balance sheet total of the regulated and non-regulated financial sector entities in the group to the total balance sheet of the group should exceed 40 percent);

- the activities of the group in, on the one hand, the insurance sector and, on the other hand, the banking and investment sectors are "significant" (i.e., each financial sector balance sheet and solvency requirements to total group balance sheet and solvency exceed 10 percent or the total balance sheet of the smallest financial sector in the group exceeds $€ 6$ billion).

- The Belgian-designated FCs are identified on the published list of conglomerates with a head of group in the EU/European Economic Area (EEA). ${ }^{8}$

\section{The scope of conglomerate supervision in Belgium is broad and provides the basis for} supervision of both regulated and unregulated entities. The main provisions for conglomerate supervision as provided in the 2005 Financial Conglomerates Royal Decree include:

- access to information from all regulated and unregulated entities that belong to the FC (Art. 21 of the Royal Decree);

- administrative sanctions to regulated institutions but the sanctioning power is limited to the context of "avoiding or trying to avoid sectoral regulation" (Art. 27 of the Royal Decree);

- supplemental supervisory elements including solvency (quantitative and qualitative requirements), risk concentrations and intra-group transactions, qualitative requirements and

\footnotetext{
${ }^{7}$ FICOD resulted in changes to four major Belgian prudential laws: the Banking Law (Law of 22 March 1993), the Insurance Law (Law of 9 July 1975), the Investment Services Law (Law of 6 April 1995), and the Law of Collective Investment Schemes (Law of 20 July 2004). In each case, the laws were revised for the respective regulated institutions of FCs (banks, insurance companies, investment firms, and collective investment management companies) to be subject to a supplementary supervision.

${ }^{8}$ See http://ec.europa.eu/internal_market/financial-conglomerates/supervision_en.htm.
} 
quantitative reporting, risk management, internal control, and suitability of management and shareholders;

- provisions for the supervisor to intervene in group structuring or group transaction if regulatory arbitrage was evident;

- determining a group level coordinator;

- role of the external auditor at the group level.

17. The EU Directives produce an uneven supervisory treatment for FCs. FICOD is explicit, stating that the existing sectoral rules for credit institutions (i.e., Capital Requirements Directive CRD) should be supplemented to the minimum level, in particular, to avoid regulatory arbitrage between the sectoral rules and those for financial conglomerates. ${ }^{9}$ FICOD also provides certain waivers to the application of supplementary FC supervision, allowing instead for sectoral consolidated supervision to be applied to certain conglomerates. According to FICOD (and relevant transposing Belgian legislation), the supervisor who identifies an FC can waive the application of conglomerates specific requirements applicable to FCs which do not simultaneously meet the two "significance" threshold requirements. ${ }^{10}$

18. Belgium has prudently opted for applying the most comprehensive regulatory regimes to its most important conglomerates. In the original identification of FCs in 2006, the former CBFA chose to apply a waiver for Dexia and $K B C$ to preserve enhanced supervisory powers at group level. In particular, by qualifying Dexia and $\mathrm{KBC}$ as financial holding companies (FHC), as opposed to mixed financial holding companies (MFHC), the two groups remained under the consolidated banking regime, thus ensuring continuity in the scope of the supervisory framework, including the application of Pillar 2 (internal capital adequacy assessment process and supervisory review) and Pillar 3 (disclosure and market discipline) requirements at the group level (Table 2). Such a choice was not available for Fortis, which met both "significance" criteria mentioned above and thus remained under weaker supervisory oversight at a conglomerate level.

19. The remaining two Belgian FCs fall under the conglomerates-specific regime. Argenta, which is predominantly a banking group, is subject to FICOD provisions, but reports to NBB on a conventional basis the consolidated capital adequacy position for its two parent holding companies,

\footnotetext{
${ }^{9}$ See paragraph 20 of introduction to FICOD.

${ }^{10}$ For example, FCs which reach the minimum level of the balance sheet for their smallest financial sector in the group (EUR 6 billion), but the ratio of each sector's balance sheet to total balance sheet of the FC falls below 10 percent.
} 
in accordance with the CRD, separately. In the case of AXA, which is predominantly active in insurance, the FICOD framework complements the current solvency regime (Solvency I Directive). ${ }^{11}$

\begin{tabular}{|c|c|c|}
\hline Domain & Financial Holding Company & $\begin{array}{l}\text { Mixed financial holding } \\
\text { company heading a FC }\end{array}$ \\
\hline CRD Pillar I & Applicable & $\begin{array}{l}\text { Applicable, except for: } \\
\text { (i.) decision } \\
\text { powers for the } \\
\text { coordination supervisor; } \\
\text { (ii.) more detailed } \\
\text { coordination } \\
\text { arrangements within } \\
\text { colleges }\end{array}$ \\
\hline CRD Pillar II & Applicable & $\begin{array}{l}\text { Not applicable to the } \\
\text { same extent }\end{array}$ \\
\hline CRD Pillar III & Applicable & Not applicable \\
\hline $\begin{array}{l}\text { Risk } \\
\text { concentration } \\
\text { supervision }\end{array}$ & Quantitative limits to be observed & $\begin{array}{l}\text { Reporting requirements } \\
+ \text { possibility of } \\
\text { thresholds/limits }\end{array}$ \\
\hline $\begin{array}{l}\text { Limits on } \\
\text { shareholdership }\end{array}$ & $\begin{array}{l}\text { Participations within non-financial } \\
\text { undertakings must be }<15 \% \text { Own Funds }\end{array}$ & None \\
\hline $\begin{array}{l}\text { Intragroup } \\
\text { transactions }\end{array}$ & None & $\begin{array}{l}\text { Reporting requirements } \\
+ \text { possibility of } \\
\text { thresholds/limits }\end{array}$ \\
\hline Liquidity & $\begin{array}{l}\text { Applicable (to calculate liquidity at the level of } \\
\text { a financial holding company, insurance } \\
\text { companies within the banking group are left } \\
\text { out of consideration) }\end{array}$ & Not applicable \\
\hline
\end{tabular}

20. The NBB's supervisory powers are uneven as a result of the fragmented EU framework

for FCs. As outlined above, the NBB retains greater powers in the cases of the two largest FCs which qualify as FHCs, but lacks certain powers (such as the possibility to impose Pillar 2 and Pillar 3 requirements) over those FCs which qualify as MFHCs. In the case of Argenta, the lack of powers is supplemented through conventional prudential reporting as per banking regime (CRD). AXA is benchmarked solely against conglomerate-specific requirements since the sectoral regime Solvency

\footnotetext{
${ }^{11}$ The current Solvency I framework has a number of shortcomings, in particular, it does not value technical provisions in a market consistent basis nor does it take account of the impact of movement in interest rate. For more details, see the 2012 ICP Assessment.
} 
I offers an incomplete group risk assessment. Importantly, the forthcoming implementation of the Solvency II framework will enhance the supervisory framework for insurance groups.

\section{The NBB should have enhanced powers over the MFHCs, some of which should be} acquired through enhancements of the EU-wide regime on FCs. The entering into force of the FICOD1 provisions in mid-2013 will partly improve the NBB's supervisory powers. ${ }^{12}$ More comprehensive reforms are being discussed at the EU level and NBB is working with the Joint Committee of the EBA, EIOPA and ESMA to review the supervisory powers and tools as it relates to MFHCs and unregulated entities. ${ }^{13}$

\section{Furthermore, the NBB should better articulate a supervisory baseline for FCs. When} mapped to the 2012 JF Principles (Annex I), it is evident that conglomerate supervision in Belgium is still largely driven by the supervisory needs for the individual groups, with relatively high deference to national discretion and sectoral group regulation. While the current differentiated supervisory treatment for FCs legitimately aimed at retaining greater supervisory powers against a backdrop of legislative loopholes inherited from the EU-wide regime, it is important that the NBB clarify in its day-to-day supervisory practices a uniform set of supervisory expectations regarding all FCs ('baseline' supervisory approach), whatever the legislative framework to which the group is subject may be. The NBB expectations should take into account international or EU best practices for FCs supervision, but also some existing shortcomings as outlined below.

\section{B. Supervisory Responsibility}

\section{The Belgian regulatory framework clearly delineates supervisory responsibilities for} coordination at the group level. The appointment and the tasks of the 'coordinator' of a FC are outlined in art. 19 and 20 of the 2005 Royal Decree along with provisions on cooperation and information exchange between the concerned supervisors. The NBB, in its role as coordinator, takes the lead among the relevant supervisors of the FCs.

\section{Arrangements for cooperation vary from sectoral cross-border colleges to less formalized supervisory contacts in FCs with limited foreign activities. The NBB is well} established as the banking group-level supervisor and takes a clear and well defined role in conducting joint home host activities related to risk assessment, CRD compliance, including ICAAP assessments and group-wide capital adequacy decisions. ${ }^{14}$ The supervisory college organized for

\footnotetext{
12 Some of the current shortcomings of the FC regimes will be corrected through further amendments in the EUlegislation. FICOD1 (to come into force by mid 2013) will address some current supervisory gaps by allowing the application of consolidated banking supervision and the supplementary conglomerate group supervision together and at the same (highest) level in a group that qualifies as a FCs. FICOD1 will result in a greater scope for supervision at the level of Argenta, but will not necessarily address the scope of supervision at the level of AXA until newly improved insurance regulations (resulting from the Solvency II application) will come into play (at present it is envisaged that Solvency II will be enforced as of 2016).

${ }^{13}$ EBA, EIOPA and ESMA's Response to the European Commission's Call for Advice on the Fundamental Review of the FC Directive (JC/2012/88).

${ }^{14}$ For more details, see the BCP detailed assessments of observance with codes and principles.
} 
$\mathrm{KBC}$ is the largest and is organized in a core college (including nine EU states) and an extended college (gathering authorities from $10 \mathrm{EU}$ states and four non-EU states). For Belfius, cross-border activities are less important and contacts with the foreign authorities are organized via an insurance college and bilateral contacts. In the case of Argenta, cooperation with the Dutch National Bank is more event-driven, while for AXA Belgium, the NBB participates in the core supervisory college for the AXA group organized by the French supervisor.

25. At the domestic level, supervisory coordination and information sharing between NBB and FSMA should be formalized. Since the introduction of the new supervisory architecture on April 1, 2011, the roles and responsibilities on NBB and FSMA were substantially transformed. The NBB is responsible for the supervision of banks and insurers, while the FSMA is responsible for the supervision of securities markets and asset management. Information flows and coordination arrangements between the two organizations as related to group-wide supervision remain work in progress. Supervisory arrangements should be defined for both normal and stress situations enabling both agencies to rely on clear arrangements and formalize communication to foster and enable effective group supervision in Belgium.

\section{Corporate Governance}

\section{Corporate governance for Belgian FCs is governed by the $\mathbf{2 0 0 5}$ Financial}

Conglomerates Royal Decree and sectoral laws and regulations. In application of the 2005 Royal Decree, the NBB applies the cross-sectoral "Internal Governance Circular." ${ }^{15}$ The circular outlines the prudential expectations and standards through a principle based framework and is not binding, except where the principle is also laid down in primary or secondary legislation (e.g. the requirement to have an audit committee). The following areas are covered:

- Qualities required of significant shareholders (Principle I);

- Adequate governance structure (Principle II);

- Allocating powers and responsibilities (Principle III);

- Plurality of managers, collegial decision-making, and distribution of tasks among senior managers (Principle IV); and

- Independent control functions (Principle V);

- Qualities required of the company officers (Principle VI);

- Remuneration policy for company officers (Principle VII);

\footnotetext{
${ }^{15}$ Circular PPB-2007-6-CPB-CPA on the former CBFA's prudential expectations on financial institutions' sound governance, March 2007 (http://www.nbb.be/doc/cp/eng/ki/circ/pdf/ppb_2007_6_cpb_cpa.pdf).
} 
- Strategic aims, enterprise values and conflicts of interest policy (Principle VIII);

- Know your structure, know your activities (Principle IX); and

- Publicity and disclosure (Principle X).

27. Financial institutions are expected to self-assess and report on their level of compliance and implementation on an annual basis. Because the principle is not legally binding, non-implementation may be possible if the institution can justify an alternative governance arrangement of equal merit, subject to approval by NBB. The circular further outlines policy directives for the self-reporting governance memorandum of the group. These include a description of the objectives and interests of the group with regard to subsidiaries, a determination of how group steering impacts the subsidiaries, allocation of responsibilities between parent company and subsidiaries, organization charts, and policies and rules governing intra-group outsourcing and management of conflicting interest.

28. The circular further elaborates on sound governance in a group context. This section outlines supervisory expectations on a group level and the applicable prudential elements as related to sound governance. These include intra-group transactions, appropriate risk management and internal control procedures, qualities required of shareholders, plurality and fitness of senior management and statutory auditor's tasks. The circular discusses the application of the principles on a cross border basis; the distribution of tasks between parent company and subsidiary, group management should not conflict with legal entity obligations, independent control functions in a group context, managing conflict of interest and plurality of functions.

29. Conflict of interest governance is especially important to observe for FCs. In a model where banking and insurances business strategies present synergy opportunities, there must be heightened standards to protecting each sector equally within the same corporate governance and risk management framework (i.e., depositors, policy holders, account holders). There must be a sufficient level of checks and balances to guard against potential conflicts of interest. Such issues are addressed in Section F - "Managing conflicts of interest" and "Plurality of functions" which provides guidance targeted at identifying, preventing and managing potential concerns.

30. Governance requirements as stated in the NBB Internal Governance Circular should be more consistently applied. In particular, conflicts of interest may result from an overlap of risk management responsibilities at both the holding company and some of its regulated subsidiaries. Such situations of conflict of interest require prompt supervisory attention as they have a potential to weaken the governance and risk management in mixed bank-insurance groups.

31. The corporate governance framework for conglomerates should be subject to more supervisory checks by the NBB. The annual self-report coupled with a review by certified external auditors provide a good check on the governance of FCs. However, periodically, this self-reporting process should be validated by NBB inspectors to ensure that both the company and external 
auditors are accurate. Back-testing confirms the integrity of system and enhances the supervisor's institutional knowledge.

32. For the FCs that are part of an MFHC, NBB supervisory reach is currently more limited. In particular, the NBB powers do not apply directly to holding companies part of the MFHCs and operate indirectly through legal provisions provided under sectoral regimes. After the implementation of FICOD1 in Belgium, all powers available for FHCs or insurance holdings will also become applicable at the level of a MFHC.

\section{Risk Management}

\section{NBB has risk management and internal control standards for the regulated entities} within an FC including sound administrative and accounting procedures. These standards and requirements (Box 2) establish an adequate framework. An FC could offer a wide variety of financial products spanning banking, insurance and securities with different risks and risk mitigation practices. In this regard, it is essential for the principles to emphasize an established enterprise-wide risk management process that appropriately captures and aggregate risk for the entire group including unregulated entities, special purpose vehicles, and off-balance sheet items.

\section{Box 2. The Requirements for FCs Risk Management}

The risk management processes shall include:

- $\quad$ sound governance and management with the approval and periodical review of the strategies and policies by the appropriate governing bodies at the level of the FC with respect to all the risks they assume;

- adequate capital adequacy policies in order to anticipate the impact of their business strategy on risk profile and capital requirements;

- $\quad$ adequate procedures to ensure that their risk monitoring systems are well integrated into their organization and that all measures are taken to ensure that the systems implemented in all the undertakings included in the scope of supplementary supervision are consistent so that the risks can be measured, monitored and controlled at the level of the FC.

The internal control mechanisms shall include:

- $\quad$ adequate mechanisms as regards capital adequacy to identify and measure all material risks incurred and to appropriately relate own funds to risks;

- $\quad$ sound reporting and accounting procedures to identify, measure, monitor and control the intragroup transactions and the risk concentration.

Source: 2005 Royal Banking and Insurance Decree.

\section{The NBB has developed a Supervisory Review and Evaluation Process (SREP). SREP is} used to assess the adequacy of risk management, internal controls and the Internal Capital Adequacy Assessment Process (ICAAP), the NBB seeking to identify areas of weakness or non- 
compliance that require supervisory attention. ${ }^{16}$ The SREP supervisory assessment process is utilized across institutions, including the holding companies. The level and intensity in application is dependent on the size and complexity of the group. The risk assessment process has three layers: 1 ) the FCs' internal control structure and internal audit; 2 ) verification by the accredited external auditors; 3) NBB's supervision through on-site and off-site work.

\section{Essential components of the SREP are the quantitative and qualitative assessment of} risks as well as their management by institutions. The following elements are of particular importance in this context :

- The institution's exposure to risks

- The adequacy of an institution's risks identification, measure and monitoring processes

- The adequacy of an institution's own funds

- The adequacy of an institution's capital resources more generally

- The permanent compliance with the $\mathrm{CRD} /$ national regulations requirements

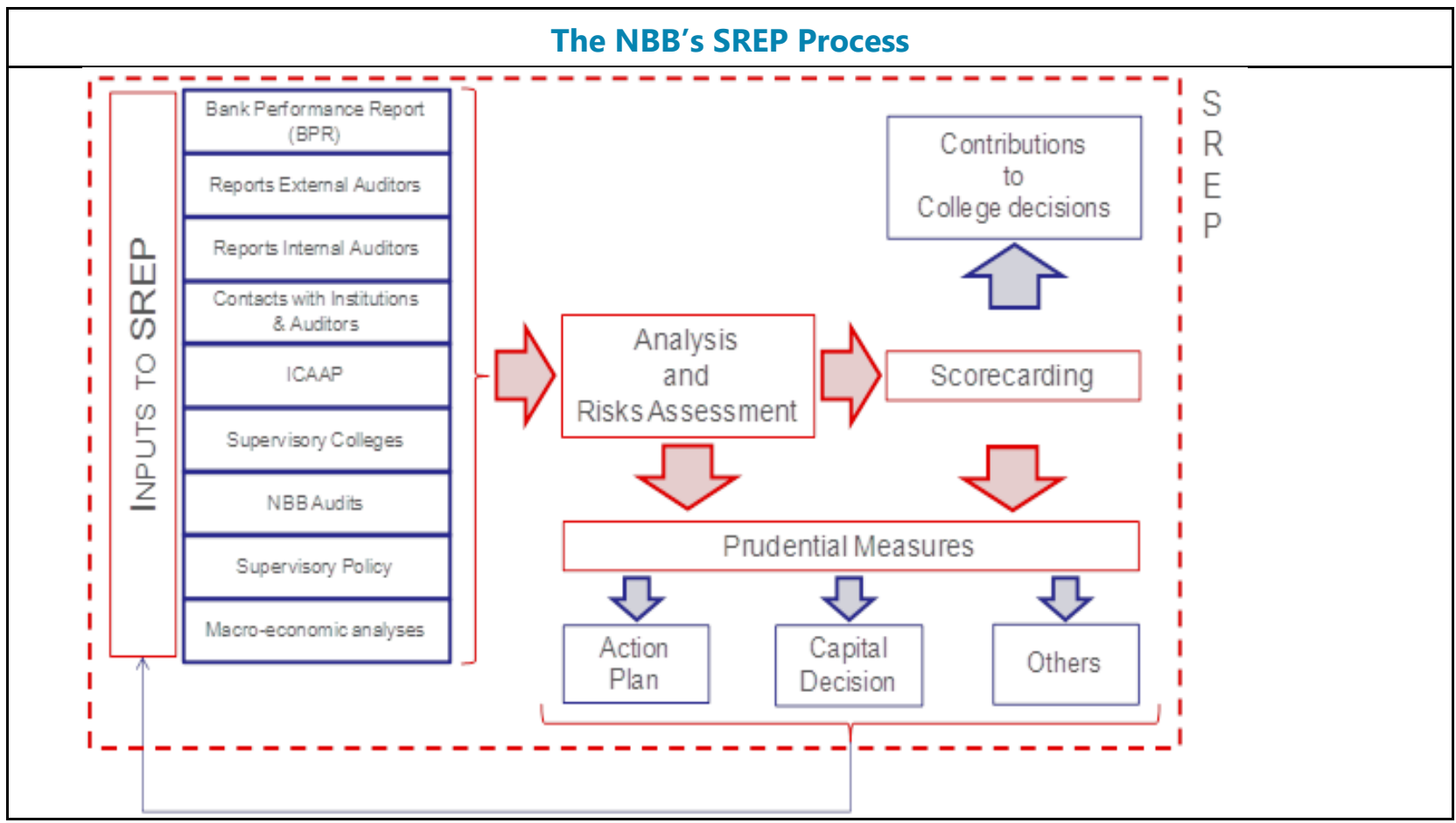

36. The scorecard system is well established within the banking sector supervisory teams. Bank scorecards are used extensively to analyze, support and document specific risk analysis of exposures as amply demonstrated in the sample ICAAP reviews. NBB recently incorporated a

\footnotetext{
${ }^{16}$ For more details, see the 2012 BCP detailed assessment of standards and codes.
} 
scorecard for the securities business which focused on operational risk. In the insurance sector, the scorecard system facilitates proper documentation and consistency of supervisory assessments and provids a structured framework to discuss supervisory issues; both internally and with insurers. Further refinements of the insurance scorecard will be made based on the upcoming Solvency II framework. ${ }^{17}$

\section{A more comprehensive scorecard discipline would further enhance NBB's group level} risk assessment. In particular, the NBB should continue the refinement of the securities and the insurance scorecards. Consistent use of scorecards across sectors would foster greater focus on all risks thus enabling a more complete and accurate group level risk assessment. Such a standardized practice would also allow the NBB to accumulate horizontal views across FCs which would become the basis for an initial benchmark for establishing a baseline risk management supervisory standard.

\section{The NBB needs to enhance its capacity to verify the quality and consistency of risk}

assessments. NBB supervisors appeared to leverage much of the work of the external auditors with regard to ensuring the accuracy of financial statements and the internal control environment. ${ }^{18}$ While the scope of the financial audit can support the accuracy of financial statements, over-reliance on this audit work to ensure that controls are properly operating and effective could lead to inaccurate supervisory views. Therefore, additional supervisory resources should be devoted to validation and back-testing.

\section{Reporting of risk concentrations and intra-group transaction to the coordinator is} made at least annually, but coverage is incomplete. For MFHCs, NBB requires the annual reporting of risk concentrations at the level of the holding company which means that any risk or transaction within the wider group would not be required to be reported. ${ }^{19}$ The $2012 \mathrm{JF}$ Principles require that FCs have in place effective systems and processes to identify, assess, and report groupwide risk concentrations, including for the purposes of monitoring and controlling those concentrations. NBB should require FCs to report on their group-wide concentrations, which would enable the supervisor to be aware of transactions and risks that could potentially impact the FC.

\section{There are no quantitative limitations for risk concentrations and intra-group transactions within FCs, although some changes are expected under EU-wide revisions. The}

\footnotetext{
${ }^{17}$ For more details see 2012 ICP detailed assessment of standards and codes.

${ }^{18}$ Historically, the Belgian supervisory model has incorporated external auditors in the supervision of their prudential entities. External auditors must be accredited by NBB, a practice that dates back to 1935 when first introduced by the Banking Commission. The accreditation process and the role of the external auditors were evaluated and updated in 2008. The external auditor contributes to many facets of supervisory work mainly comprising an assessment of the internal control environment, certification of prudential returns, conducting a special report at the request of the bank, and assessing the soundness of measures taken to safeguard client assets for institutions subject to Market in Financial Institutions Directive. There are a number of checks and balances to ensure that professional standards are observed as well as standards for the attestation of financial statements and internal controls environment.

${ }^{19}$ "Wider group" means the broader group to which the FC belongs, e.g., in cases where the FC is part of a larger diversified conglomerate with both financial and non-financial entities (http://www.bis.org/publ/joint29.pdf).
} 
NBB has not placed quantitative limitations for risk concentrations and intra-group transactions for the conglomerate regime even though some form could be achieved through FICOD. For certain "waived" FCs, NBB indirectly applies the CRD regime for risk concentrations. ${ }^{20}$ With the enactment of FICOD1, the NBB will be empowered to require measures to protect entities against contagion within the group and impose limits on risk concentration. For these enhanced powers, NBB is anticipating improved technical standards at the European level.

\section{Under the NBB's conglomerate regime, as spelled out in the 2005 Financial} Conglomerate Royal Decree, stress testing is currently not a requirement. In practice, when the NBB assesses the ICAAP for FCs that are predominantly present in the banking sector, this will include stress testing. While stress testing should occur regularly for the banking and insurance subgroups of a financial conglomerate, FICOD 1 demands the coordinator to decide the appropriateness, parameters and timing of a stress test for an individual FC as a whole. In the same vein, the JF Principles emphasize the importance of covering all risks, including off-balance sheet items and special purpose vehicles. The 2008 crisis has demonstrated that Belgian FCs were overly exposed to financial markets, outlining the need to be able to stress the overall risk profile at the group level, including cross-border unregulated entities.

\section{The NBB's financial analysis of the FCs would benefit from a more macro analytical} approach. While the current population of conglomerates is limited (i.e., there are four Belgian FCs), the discipline of having a peer group for comparison is essential to inform a supervisor's assessment not only of institutions but of the market segment. NBB's Macro-Financial Committee and Risk Committee (MFC-RC) are well positioned to carry-out such a workstream by its technical ability to blend the macro and micro aspects together within the cross-sectoral multi-disciplinary structure. In this context, the 2013 annual risk review foresees different in-depth cross sectoral analyses (i.e., for interest rate risk, liquidity, business models, etc.) which will be steered and coordinated by the RC and the MFC.

\section{E. Capital}

\section{According to the NBB supervisory framework, each FC is subject to one specific} solvency tests at consolidated level as a supplement to the relevant sectoral rules. From a legal perspective, capital adequacy tests for FCs are prescribed in the Royal Banking and Insurance Decree of 2005, which allows NBB to apply a supplementary test for conglomerates on top of the different sectoral approaches. The solvency tests (Box 3) applied by the NBB - the Building Block Method and the Aggregation and Deduction Method derive from the FICOD and the 1999 JF Capital Adequacy Principles. The approach allows for alternative measurement techniques for the assessment of capital adequacy for heterogeneous FCs rather than promoting a single technique for universal application. $^{21}$

\footnotetext{
${ }^{20}$ For more details see $2012 \mathrm{BCP}$ detailed assessment of standards and codes.

${ }^{21}$ Joint Forum, Capital Adequacy Paper and Supplement, 1999.
} 


\section{The two existing methods to assess capital adequacy at FC level are prudently}

calibrated. Under the building block method, consolidated accounts are used as a basis to calculate their own funds and under the Aggregation and Deduction Method, the book value of the intra group participations are added to the solvency requirements. Additionally, NBB only allows instruments that are eligible as regulatory capital to be taken into account in the own funds at the consolidated level. Regulatory own funds may include subordinated debt meeting some eligibility criteria (minimum five years maturity) but their recognition at consolidated level are subject to same limitation applicable under the sectoral rules (maximum 100 percent of Tier 1 for banking sector and maximum 50 percent of the capital requirements for the insurance sector). 
Box 3. Capital Adequacy Tests Applied by NBB at the Conglomerate Level

The building block method: under this method the calculation of the capital adequacy requirements at the level of the FC shall be carried out on the basis of the consolidated accounts. The supplementary capital adequacy requirements shall be calculated as the difference between: (i) the own funds of the FC calculated on the basis of the consolidated position of the group (the elements eligible are those that qualify in accordance with the relevant sectoral rules); and (ii) the sum of the solvency requirements for each different financial sector represented in the group calculated in accordance with the corresponding sectoral rules.

The aggregation and deduction method: The calculation of the supplementary capital adequacy requirements of the FC shall be carried out on the basis of the solo accounts of each of the entities in the group. The supplementary capital adequacy requirements shall be calculated as the difference between: (i) the sum of the own funds of each regulated and non-regulated financial sector entity in the FC; the elements eligible are those which qualify in accordance with the relevant sectoral rules; and (ii) the sum of the solvency requirements for each regulated and non-regulated financial sector entity in the group; the solvency requirements shall be calculated in accordance with the relevant sectoral rules, and the book value of the participations in other entities of the group.

Source: 2005 Royal Banking and Insurance Decree.

45. The consistent application of the FC capital adequacy framework is not evident. In order to ensure a consistent application of capital tests across all FCs, the NBB should consider guiding more clearly how the capital adequacy tests should be applied in practice.

46. NBB's conglomerate supervisory regime could benefit from utilizing capital adequacy measures that are more targeted to detecting double or multiple gearing. For example, NBB may wish to assess more systematically the level of double gearing and its potential impact on the capital position of the parent company and of the operating entity. Based on such assessments, the NBB should be able to request, as necessary, a stronger capital base at the level of the holding company.

\section{The review of ICAAP is embedded with NBB's SREP framework, but a broader use} would be recommended. The ICAAP assessment constitutes a major component within NBB's supervisory regime for banking groups (including KBC, Belfius, and Argenta). The analysis involves an evaluation of both Pillar 1 and Pillar 2 risks (through onsite and offsite inspections) plus the results of stress tests to determine if a capital decision is required for a supervisory add-on (Figure 4). This should be applied to all holding companies structures (including MFHC) and not limited to institutions that have been categorized as FHCs. 


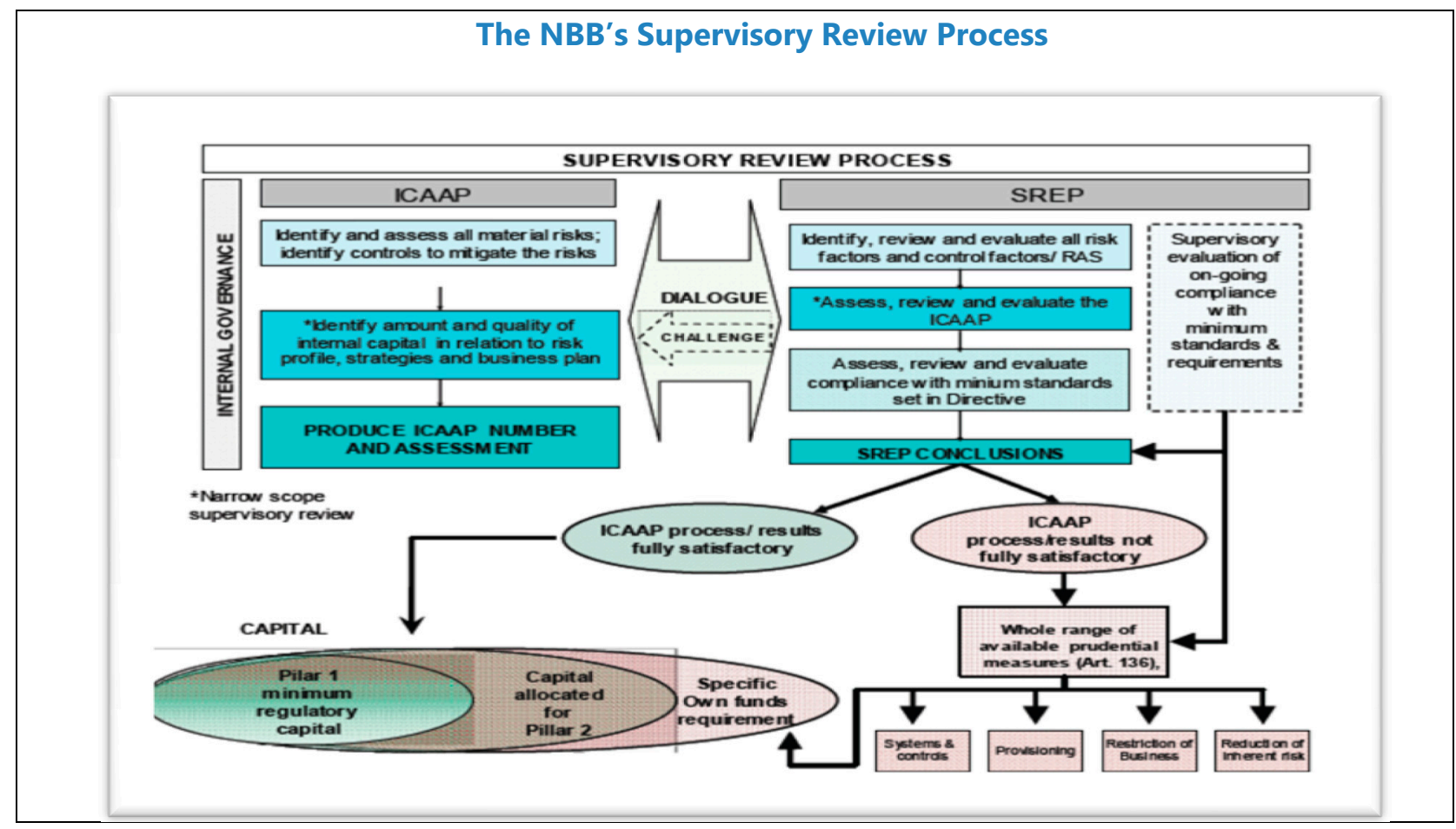

48. A more consistent cross-sectoral approach to capital assessment would be desirable.

ICAAP assessments conducted by NBB include a review of credit, operational, market, and asset and liability management. For some FCs, other sectors (insurance and securities) were included to a certain extent. In practice, the SREP and risk assessment processes are generally driven by the predominant sector, which is mainly explained by the fact that FCs in Belgium are largely dominated by one sector. This may lead to certain loopholes. In this regard, if an FC is predominantly banking, insurance and securities risks are incorporated into a banking model. Similarly, for an insurerdominated conglomerate, the lesser banking risks are evaluated through an insurance framework. NBB is in the process of finalizing scorecards for the insurance and securities sector, which should support a higher level of intensity with regard to cross-sector analysis within ICAAP.

49. The Joint Assessment Process plays a key role in assessing group wide risks and group level capital adequacy. The NBB utilizes the supervisory college process and information from host supervisors to supplement and complete a holistic view of the FC. Interactive sessions are conducted by the NBB, as the home supervisor, to discuss host risk assessments, home-host ICAAP assessments, and CRD compliance. Within the college, there are discussions of the capital assessments leading up to a Joint Capital Decision. Detailed minutes document and memorialize the process and result.

\section{Some shortcomings in the capital measurement framework for conglomerates are} induced by the application of the sectoral European directives. The corresponding sectoral Directives display differences between the insurance and banking sector stemming from different thresholds set and also from the distinction between intra-sectoral and cross-sectoral deductions for banks' investments (Table 4). This could give rise to regulatory arbitrage, i.e., the possibility of 
transferring a holding (in a bank or in an insurer) from a banking group to an insurance group or vice versa. Potentially, depending on the consolidation method used, it could be more advantageous if holdings of more than 10 percent and less than 20 percent are held by an insurer rather than a bank in order to avoid deduction (and thus overstate group capital). However, such cases have not been identified in Belgium.

\begin{tabular}{|c|c|c|}
\hline & Holdings in banks & Holdings in insurance companies \\
\hline Insurance group & $\begin{array}{l}\text { Deduction if }>20 \% \text { of the held } \\
\text { entity or, if less, in case of } \\
\text { durable link }\end{array}$ & $\begin{array}{l}\text { Deduction if }>20 \% \text { of the held } \\
\text { entity or, if less, in case of durable } \\
\text { link }\end{array}$ \\
\hline Banking group & $\begin{array}{l}\text { Deduction if }>10 \% \text { of the held } \\
\text { entity or, if less, the total } \\
\text { amount exceeding } 10 \% \text { of own } \\
\text { funds of the holder }\end{array}$ & $\begin{array}{l}\text { Deduction if }>20 \% \text { of the held } \\
\text { entity or, if less, in case of durable } \\
\text { link }\end{array}$ \\
\hline
\end{tabular}

\section{The NBB should take into consideration risks stemming from double leveraging.}

Double leveraging refers to the financing strategy where the parent company issues debt and downstreams the proceeds as equity investment in its subsidiaries. The supervisory concern with double leverage arises on the one hand from the debt service requirements on the subsidiaries to repay the parent's debt and on the other hand from the lower capital available at the conglomerate level to absorb losses. The presence of double leveraging a bank can complicate the decisions on cutting dividends at the subsidiary level, which have the potential to affect the capacity of the holding company to service its debt. It is good supervisory practice to introduce metrics for double leveraging (i.e., in the U.S., supervisors are using several indicators to monitor multiple leveraging, including equity investment in subsidiaries / equity capital and variations of this).

\section{For MFHCs, the NBB's authority to assess liquidity, as part of the supplemental} conglomerate regime is weak. At present, liquidity is assessed on an individual and consolidated basis at the level of a FHC; however, insurance companies within the banking group are left out of consideration. ${ }^{22}$ If the group is deemed to be a MFHC, then liquidity at the group level is however not monitored, which represents a substantial regulatory gap. Potentially, there could be situations where the NBB is unable to impose a liquidity and funds management supervisory regime at the group level. Lessons learned from the recent crisis demonstrate the critical nature of liquidity risk and the high degree of contagion present in a liquidity run. Further improvements in the area of liquidity monitoring at the level of FCs should arise from further FICOD revisions (FICOD 2).

\footnotetext{
${ }^{22}$ Notably, in general, considering insurance entities in the group's overall position would artificially improve liquidity due to the relatively high level of unencumbered liquid assets and low level of short term liabilities on their balance sheet.
} 
53. A review of the reports received by NBB for capital and liquidity support the concerns regarding a lack of uniformity and supervisory baseline. A summary report indicating the type and frequency of capital and liquidity reports received by the NBB indicate that FHCs are subject to more frequent and detailed reporting, while less information is received from MFHCs. Further, there was not enough consistency in the way in which capital (for banks) and solvency (for insurers) were reported. Uniformity would lessen the risk of a gap and further support the establishment of a supervisory baseline. Furthermore, a more documented process of interaction between the banking and insurance supervision departments within the NBB would also support a more articulated supervisory approach for FCs.

\section{CONCLUSIONS AND RECOMMENDATIONS}

54. Due to their economic reach and their use of regulated and unregulated entities across sectoral boundaries, FCs present a challenge for sector specific supervisory oversight. In hindsight, the crisis exposed situations in which regulatory requirements and oversight did not fully capture all of the activities of FCs or fully consider the impact and cost that these activities may pose to the financial system. A stronger supervisory framework for FCs is necessary to fill these gaps. The international community acknowledged the need for such changes through the adoption of the 2012 revised JF Principles for the Supervision of FCs.

55. The Belgian supervisory approach to FCs has been pragmatic, but has resulted in a very fragmented framework. Supervisory choices have allowed the NBB to retain greater supervisory powers over its two largest FCs, where the sectoral supervisory regime (CRD) was preferred to specific conglomerate supervision (FICOD) because of its wider scope and intensity in terms of prudential requirements. However, this approach has also resulted in a much differentiated supervisory framework across FCs, more intrusive and intense for FHCs, but with substantial regulatory gaps in the case of MFHCs.

56. The supervisory framework for FCs needs to be improved in a number of key areas:

- enhancing the regulatory and supervisory authority over MFHCs;

- improving supervisory tools for FCs in the area of capital measurement and adequacy, liquidity, and monitoring of group-wide and intra-group risks;

- streamlining supervisory processes by making more consistent use of scorecards across sectors; performing more frequent back-testing of auditors' findings; and better organizing cooperation with domestic and relevant foreign supervisors.

57. Supervisory powers over MFHCs need to be considerably enhanced. In particular, the NBB should have a legal basis to require the introduction of a capital planning process at the level of the MFHCs to take into account the group-wide risk profile and appetite and possible negative impacts to the capital position from the material entities and relevant business risks. The NBB should also have the power to require forward-looking stress tests to support the capital planning process. 
Furthermore, liquidity should be monitored across all FCs (including MFHCs) and the NBB should have the power to impose sound governance principles over non-regulated entities which head the conglomerate (holding companies).

\section{Some existing supervisory tools could be streamlined and applied more uniformly to} better capture FC-specific risks. In particular, the NBB should consider applying more conservative solvency tests (i.e., Total Deduction Method) to determine the true loss absorbency of the parent company; monitor multiple leveraging of capital within FCs; introduce reporting of group-wide risk concentrations; and consider setting limits on intra-group risks and transactions for all FCs. The existing requirements for corporate governance and reducing conflicts of interests should also be more consistently applied across FCs. A more uniform application of prudential requirements will naturally lead to the development of a supervisory baseline for FCs.

59. Finally, the NBB is encouraged to continue its efforts to improve offsite and onsite supervisory processes. In particular, improvement to the risk scorecards for the insurance and the securities sectors would enable a higher level of intensity and more consistent assessment of risks across sectors. Furthermore, it is recommended that the NBB reduce reliance on external auditor's findings and strengthen its in-house expertise to perform a more intrusive monitoring of financial institutions. It would be beneficial for the NBB to formalize the cooperation with FSMA and to better articulate the approach to lead supervisor of cross-border conglomerates.

60. Taken together, advancements in the approach to supervision of FCs would facilitate a better monitoring of cross-sectoral risks and enable horizontal comparisons across the sector. While the current population of conglomerates is limited, the discipline of having a peer group for comparison is essential to inform a supervisor's assessment not only of institutions or groups, but of the market segment. The NBB is well positioned to undertake this work through its ability to blend the macro and micro aspects of FCs supervision within its cross-sectoral and multi-disciplinary internal committees.

\section{Recent and pending changes in the relevant EU-wide framework should enable} gradual enhancements of the Belgians-specific framework. As outlined above, the current EU framework for FC supervision has important gaps which directly translate into incomplete national supervisory frameworks. Therefore, the comprehensive revision of $\mathrm{FICOD}_{1}{ }^{23}$ including its alignment to the recently adopted JF Principles, could improve the Belgian supervision of FCs in many areas, such as supervisory powers, governance, capital adequacy, and liquidity. However, it is important to bear in mind that such changes will take time to come into effect. By clarifying its own supervisory expectations in the area of FCs supervision, the NBB will be able to effectively address remaining gaps and constructively influence the EU-wide regulatory process.

\footnotetext{
${ }^{23}$ http://ec.europa.eu/internal_market/financial-conglomerates/supervision_en.htm\#legislation.
} 


\section{Appendix I. Group Requirements-Mapping European and Belgium Directives with 2012 Joint Forum Principles ${ }^{24}$}

\begin{tabular}{|c|c|c|c|c|c|c|c|}
\hline & $\begin{array}{c}\text { Joint Forum } \\
\text { Principles } 2012^{25}\end{array}$ & Solvency II & CRD IV & FICOD & $\begin{array}{c}\text { NBB } \\
\text { (FC regime) }\end{array}$ & $\begin{array}{l}\text { NBB (Consolidated } \\
\text { banking approach - } \\
\text { applied in practice!!) }\end{array}$ & NBB SIFI regulation \\
\hline Capital & $\begin{array}{l}\text { 15. Supervisors } \\
\text { should require that } \\
\text { the FC: } \\
\text { 15(i) maintains } \\
\text { adequate capital on } \\
\text { a group-wide basis } \\
\text { to act as a buffer } \\
\text { against the risks } \\
\text { associated with the } \\
\text { group's activities; } \\
\text { 15(ii) develops } \\
\text { capital management } \\
\text { policies that are } \\
\text { approved and } \\
\text { regularly reviewed } \\
\text { by the board, and } \\
\text { that include a clearly } \\
\text { and formally } \\
\text { documented capital } \\
\text { planning process } \\
\text { that ensures }\end{array}$ & $\begin{array}{l}\text { Articles } 218 \text { to } \\
\text { 243: Group } \\
\text { Solvency } \\
\text { requirement at } \\
\text { the level of } \\
\text { ultimate parent } \\
\text { (which includes } \\
\text { regulated } \\
\text { insurance holding } \\
\text { companies and } \\
\text { mixed financial } \\
\text { holding } \\
\text { companies). }\end{array}$ & $\begin{array}{l}\text { Article } 10 \text { CRR } \\
\text { and Articles } 122 \\
\text { to } 130 \text { CRD: } \\
\text { Capital } \\
\text { requirement at } \\
\text { consolidated } \\
\text { level (which } \\
\text { includes } \\
\text { financial } \\
\text { holding } \\
\text { companies and } \\
\text { mixed financial } \\
\text { holding } \\
\text { companies) }\end{array}$ & $\begin{array}{l}\text { Article 6: } \\
\text { Capital } \\
\text { requirement at } \\
\text { the level of the } \\
\text { mixed financial } \\
\text { holding } \\
\text { company. }\end{array}$ & $\begin{array}{l}\text { legal basis in art. } \\
49 \text { bis of the } \\
\text { Banking Law }{ }^{26} \\
\text { Art. } 9 \text { Royal } \\
\text { Decree of } 21 \\
\text { November } 2005 \\
\text { on Conglomerate } \\
\text { Supervision } \\
\\
\rightarrow \text { in the annex to } \\
\text { this Royal Decree } \\
\text { are the methods to } \\
\text { calculate the } \\
\text { supplementary } \\
\text { capital required at } \\
\text { the level of the } \\
\text { conglomerate (in }\end{array}$ & $\begin{array}{l}\text { Art. } 49 \text { of the Banking } \\
\text { Law (legal basis for } \\
\text { applying group } \\
\text { supervision at the } \\
\text { banking level) refers } \\
\text { back to article 43, } \\
\text { which is the legal basis } \\
\text { for applying the capital } \\
\text { requirements (pillar } 1 \\
\text { and pillar 2) } \\
\text { Art. } 49 \\
\text { § 1. [...] } \\
\text {. } \\
\text { § 2. [...] } \\
\text { [[The standards and } \\
\text { obligations set out in } \\
\text { Articles 20ter and 43, }\end{array}$ & \\
\hline
\end{tabular}

\footnotetext{
${ }^{24}$ Information in the table taken from EBA, EIOPA, ESMA's Repsonse to the European Commission's Call for Advice on the Fundamental Review of the FCs Directive. 2 October $2012(\mathrm{JC} / 2012 / 88)$

25 http://www.bis.org/publ/joint29.pdf

${ }^{26}$ NBB indicates that the Royal Decree 21 November 2005 on conglomerate supervision is virtually identical to FICOD. For the purpose of this principled-based mapping, the actual text is not referenced in detail.
} 
compliance with

capital requirements

on a group-wide

and regulated entity

basis; and

15(iii) considers and

assesses the group-

wide risk profile

when undertaking

capital

management.

16. Supervisors

should require that

the capital adequacy

assessments

undertaken by the

FC consider group-

wide risks, including

those undertaken by

unregulated entities

within a FC, and that

these assessments

soundly address

third party

participations and

minority interests.

17. Supervisors

should require that

capital adequacy

assessment and

measurement

techniques consider

double or multiple

gearing.

18. Supervisors

should require that

capital adequacy

assessment and there you can find $\S \S 1$ to 3], may be

the principles on

avoiding double

gearing, excessive

leverage, ....)

institution and its enforced on the basis

of the consolidated

position of the credit

subsidiaries. The

provisions of Article

43, §§ 5 and 6 shall

apply in this case by analogy.]

Art. 43

[§ 1. Without prejudice to the legal provisions on the regulatory

measures applicable

to credit institutions,

[the Bank] shall

determine the

following on monetary

grounds, by means of

a regulation and in

accordance with the

provisions of

European law:

a) the standards on

solvency, liquidity and

concentration of risks,

and other restrictions

to be adhered to by

credit institutions or

by categories of credit institution;

b) the standards to be adhered to on

investments made by 


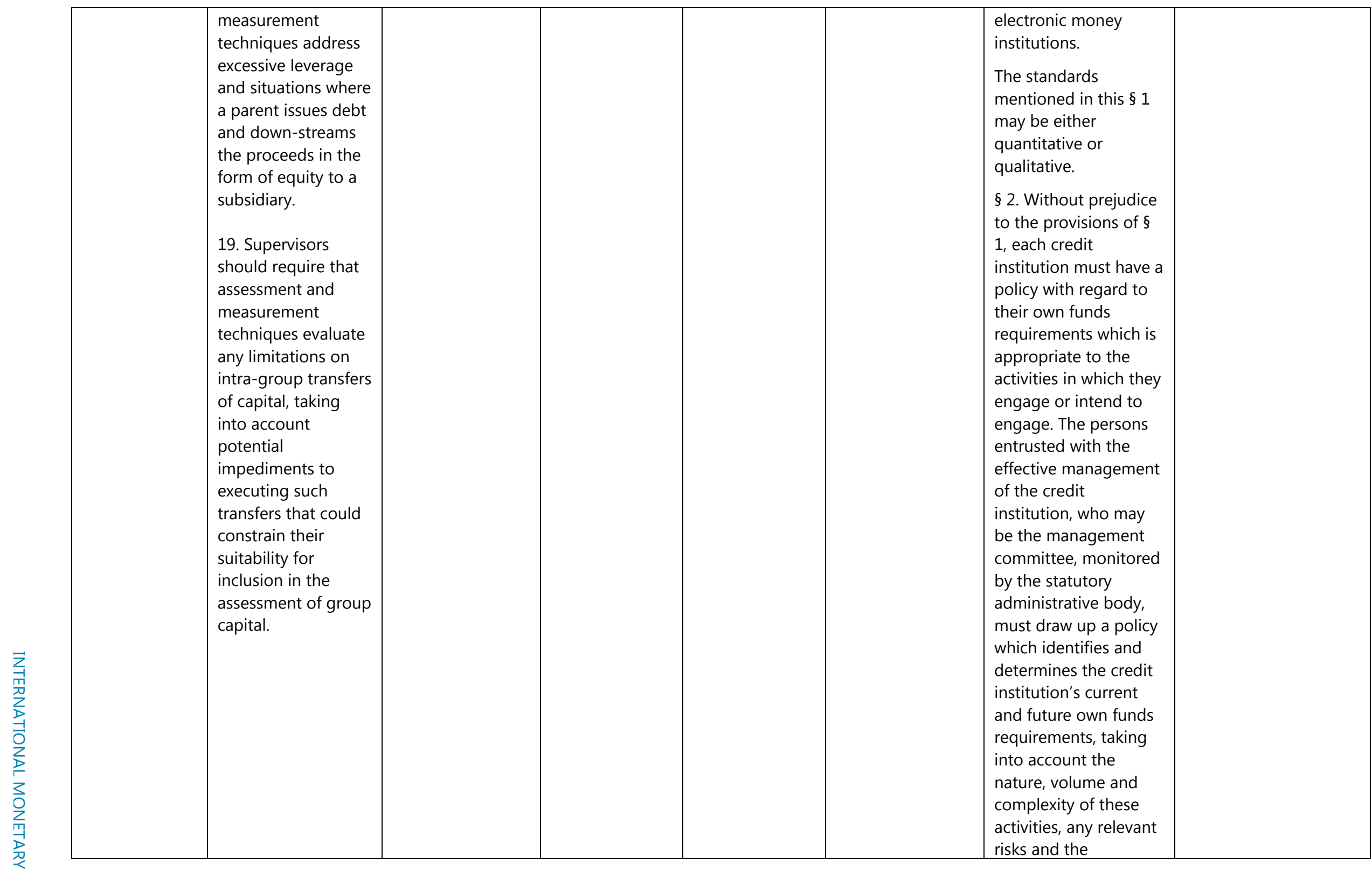




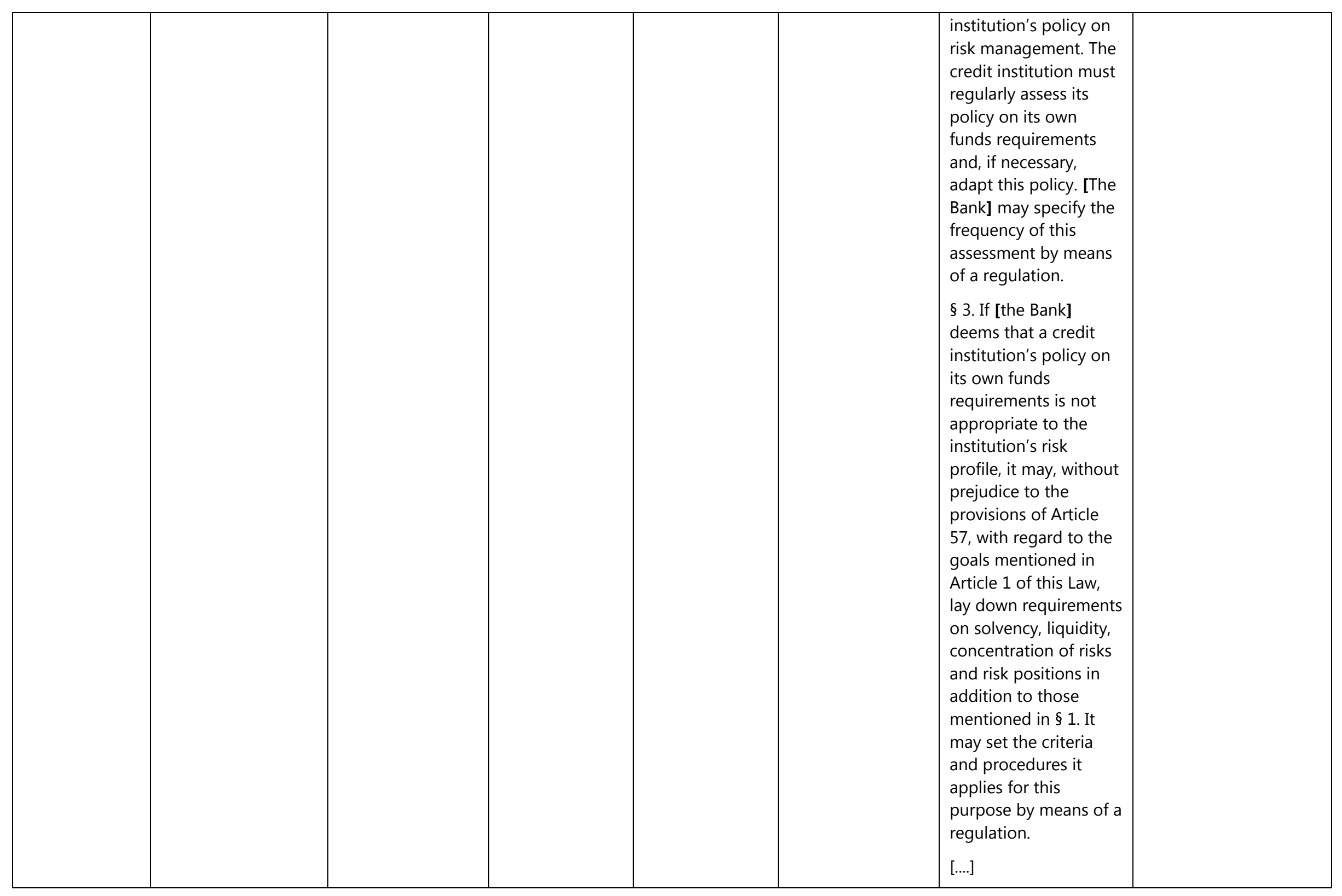




\begin{tabular}{|c|c|c|c|c|c|c|}
\hline & & & & & & $\begin{array}{l}\rightarrow \text { The actual capital } \\
\text { rules are in the NBB's } \\
\text { Own Funds regulation } \\
\text { of } 15 \text { Nov } 2011+ \\
\text { detailed circulars } \\
\text { explaining providing } \\
\text { guidance for this Own } \\
\text { Funds regulation (and } \\
\text { thereby incorporating } \\
\text { international } \\
\text { guidelines stemming } \\
\text { from EBA and BCBS) }\end{array}$ \\
\hline $\begin{array}{c}\text { Risk } \\
\text { Concentration }\end{array}$ & $\begin{array}{l}\text { 28. Supervisors } \\
\text { should require that } \\
\text { the } F C \text { has in place } \\
\text { effective systems } \\
\text { and processes to } \\
\text { manage and report } \\
\text { group-wide risk } \\
\text { concentrations and } \\
\text { intra-group } \\
\text { transactions and } \\
\text { exposure s. }\end{array}$ & $\begin{array}{l}\text { Article 244: At } \\
\text { least } \\
\text { annually reporting } \\
\text { of } \\
\text { significant risk } \\
\text { concentrations at } \\
\text { the } \\
\text { level of the group. } \\
\text { To } \\
\text { be further } \\
\text { specified in } \\
\text { implementing } \\
\text { measures. }\end{array}$ & $\begin{array}{l}\text { Articles } 376 \text { to } \\
392 \\
\text { CRR At least } \\
\text { twice a } \\
\text { year reporting } \\
\text { of risk } \\
\text { concentrations } \\
\text { under } \\
\text { the large } \\
\text { exposures } \\
\text { regime. } \\
\text { Requirements } \\
\text { include } \\
\text { quantitative } \\
\text { limits. }\end{array}$ & $\begin{array}{l}\text { Article 7: At } \\
\text { least } \\
\text { annually, } \\
\text { reporting } \\
\text { of significant } \\
\text { risk } \\
\text { concentrations. } \\
\text { No } \\
\text { quantitative } \\
\text { limits } \\
\text { (suggested } \\
\text { threshold of } \\
\text { 5\%). }\end{array}$ & $\begin{array}{l}\text { legal basis in art. } \\
\text { 49bis of the } \\
\text { Banking Law + } \\
\text { Art. } 10 \text { Royal } \\
\text { Decree of } 21 \\
\text { November } 2005 \\
\text { on Conglomerate } \\
\text { Supervision }\end{array}$ & $\begin{array}{l}\text { see references for } \\
\text { "capital" } \\
\text { The actual detailed risk } \\
\text { concentration rules are } \\
\text { again in the Own Fund } \\
\text { regulation of } 15 \text { Nov. } \\
2011 \\
\text { large exposure = } \\
\text { exceeds } 10 \% \text { of own } \\
\text { funds } \\
\text { Limitations of } 25 \% \text { of } \\
\text { the own funds for an } \\
\text { exposure to a client or } \\
\text { a group of connected } \\
\text { clients }\end{array}$ \\
\hline $\begin{array}{l}\text { Intra-Group } \\
\text { transactions }\end{array}$ & $\begin{array}{l}\text { 19. Supervisors } \\
\text { should require that } \\
\text { assessment and } \\
\text { measurement }\end{array}$ & $\begin{array}{l}\text { Article } 245: \text { At } \\
\text { least } \\
\text { annually reporting } \\
\text { of } \\
\end{array}$ & $\begin{array}{l}\text { Falls under the } \\
\text { scope } \\
\text { of consolidated } \\
\text { supervision and }\end{array}$ & $\begin{array}{l}\text { Article 8: At } \\
\text { least } \\
\text { annually, } \\
\text { reporting }\end{array}$ & $\begin{array}{l}\text { legal basis in art. } \\
49 \text { bis of the } \\
\text { Banking Law + }\end{array}$ & $\begin{array}{l}\text { Power to set limits on } \\
\text { exposures to related } \\
\text { parties can be found in }\end{array}$ \\
\hline
\end{tabular}




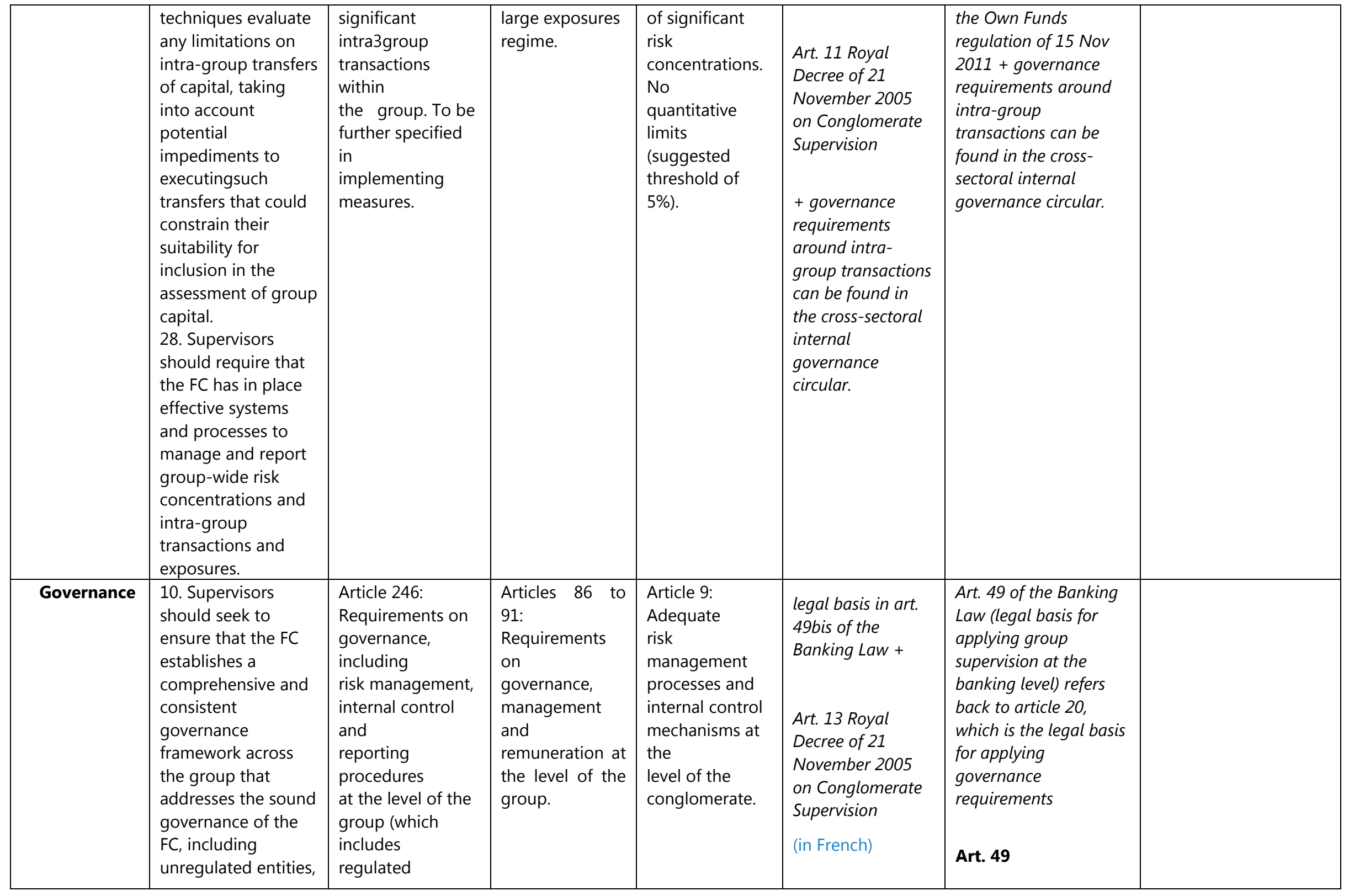




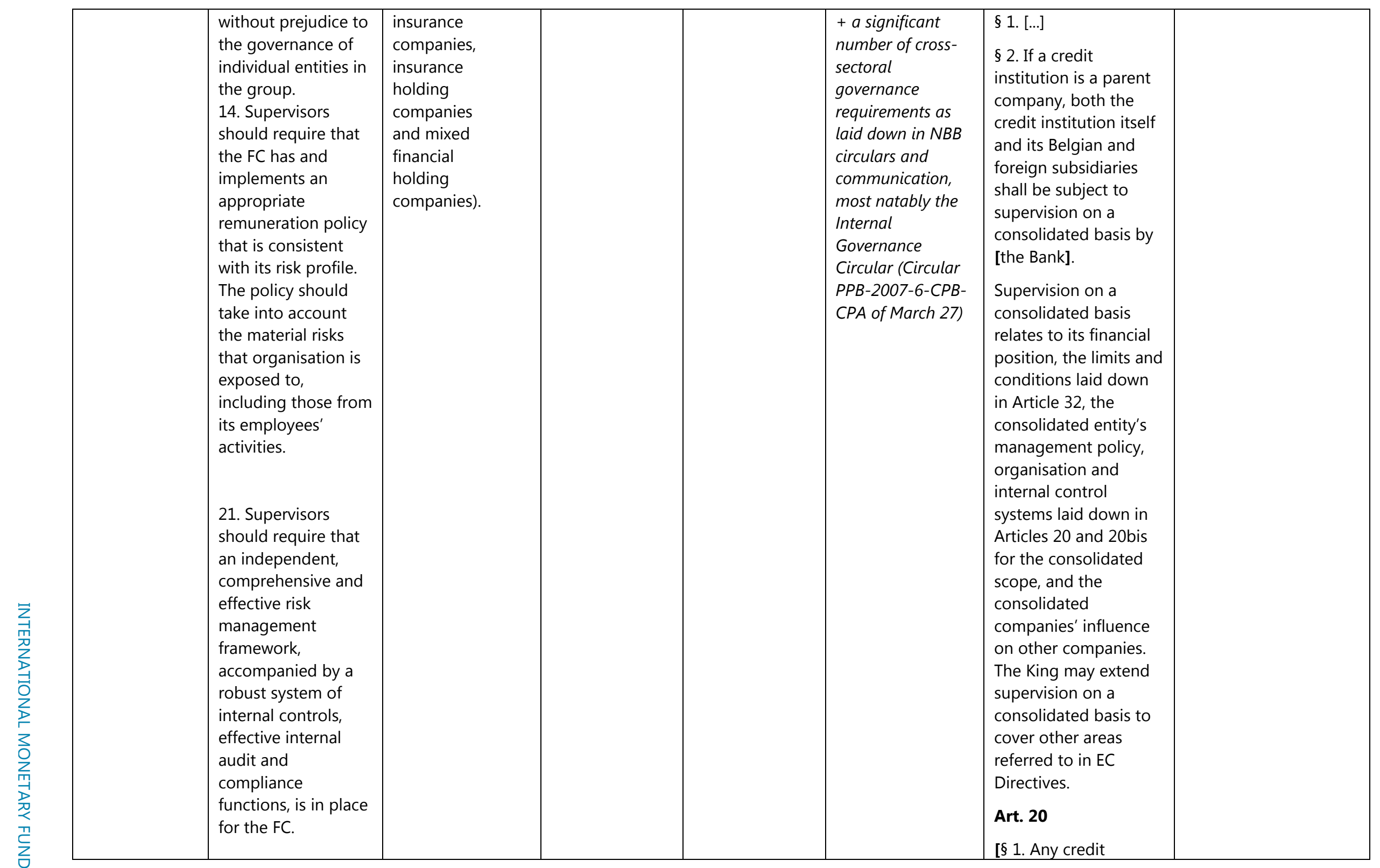




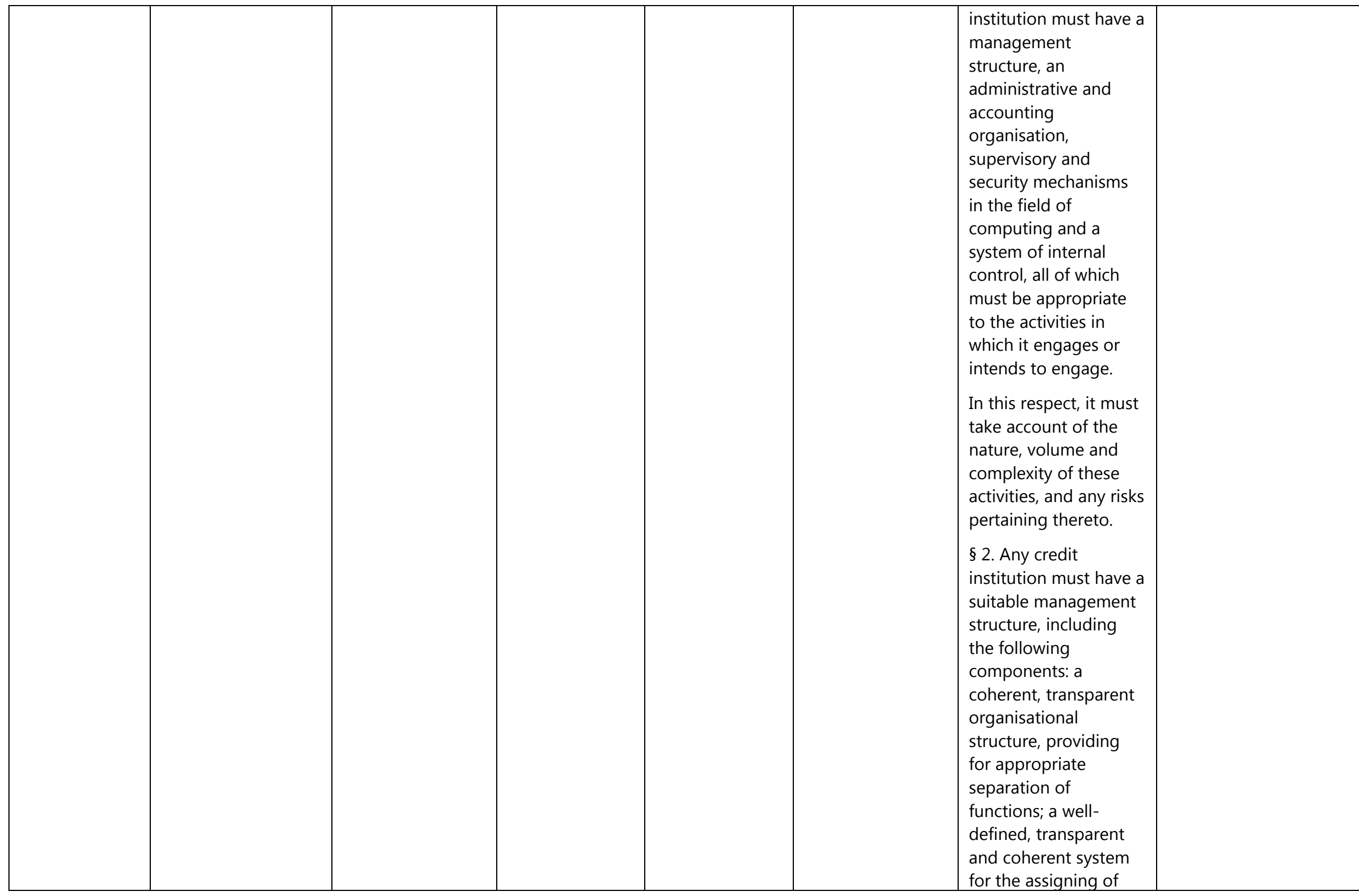




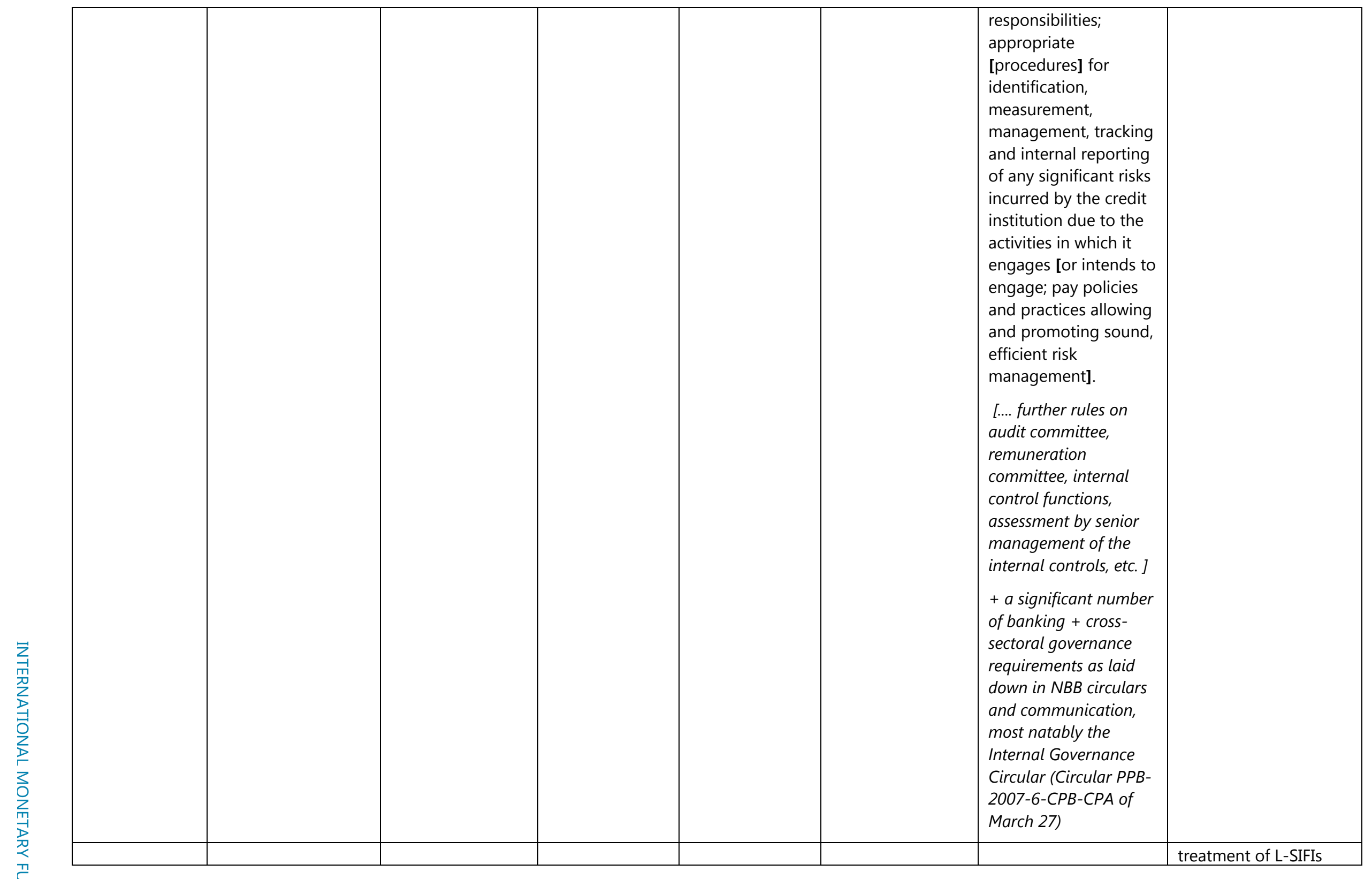




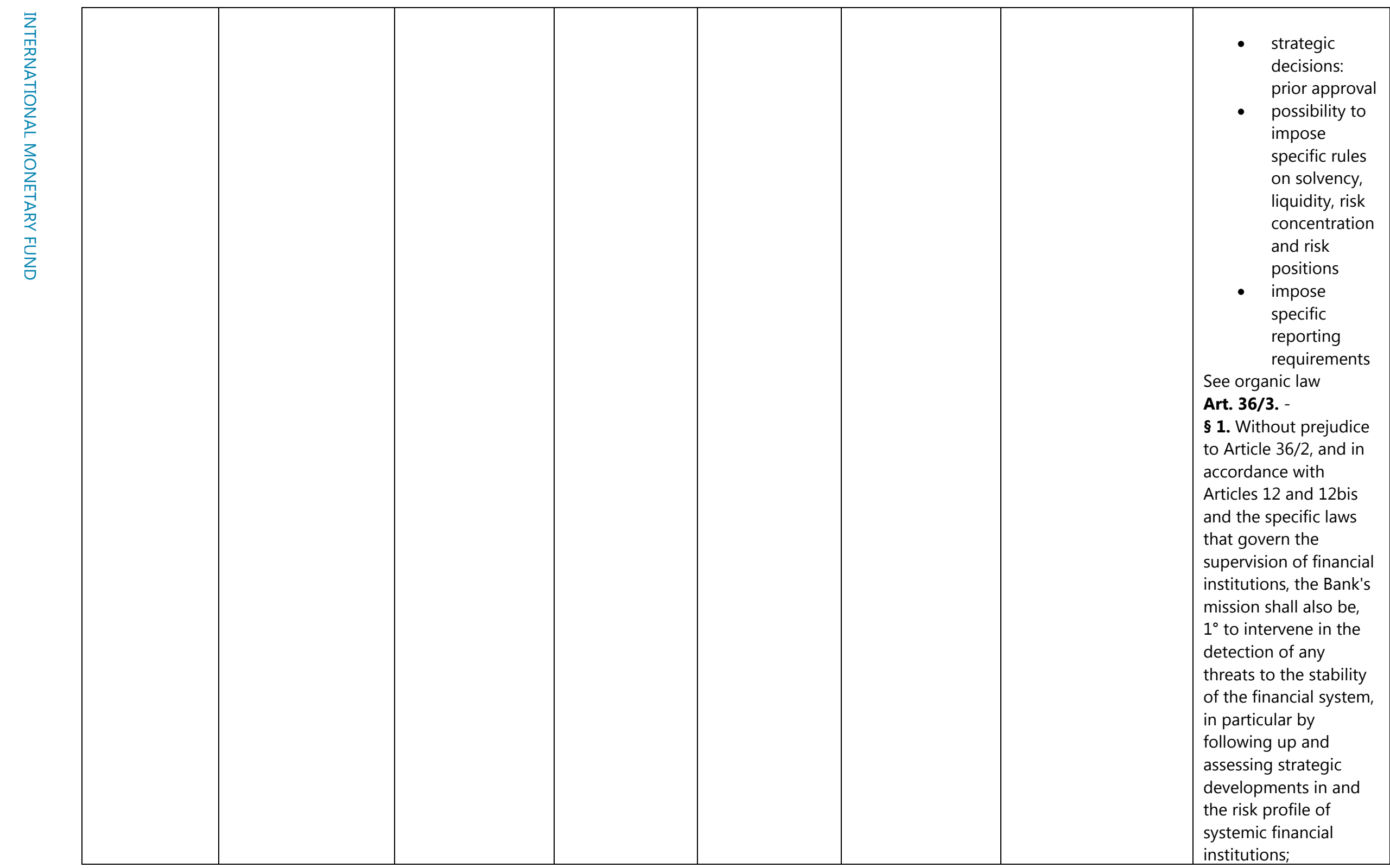




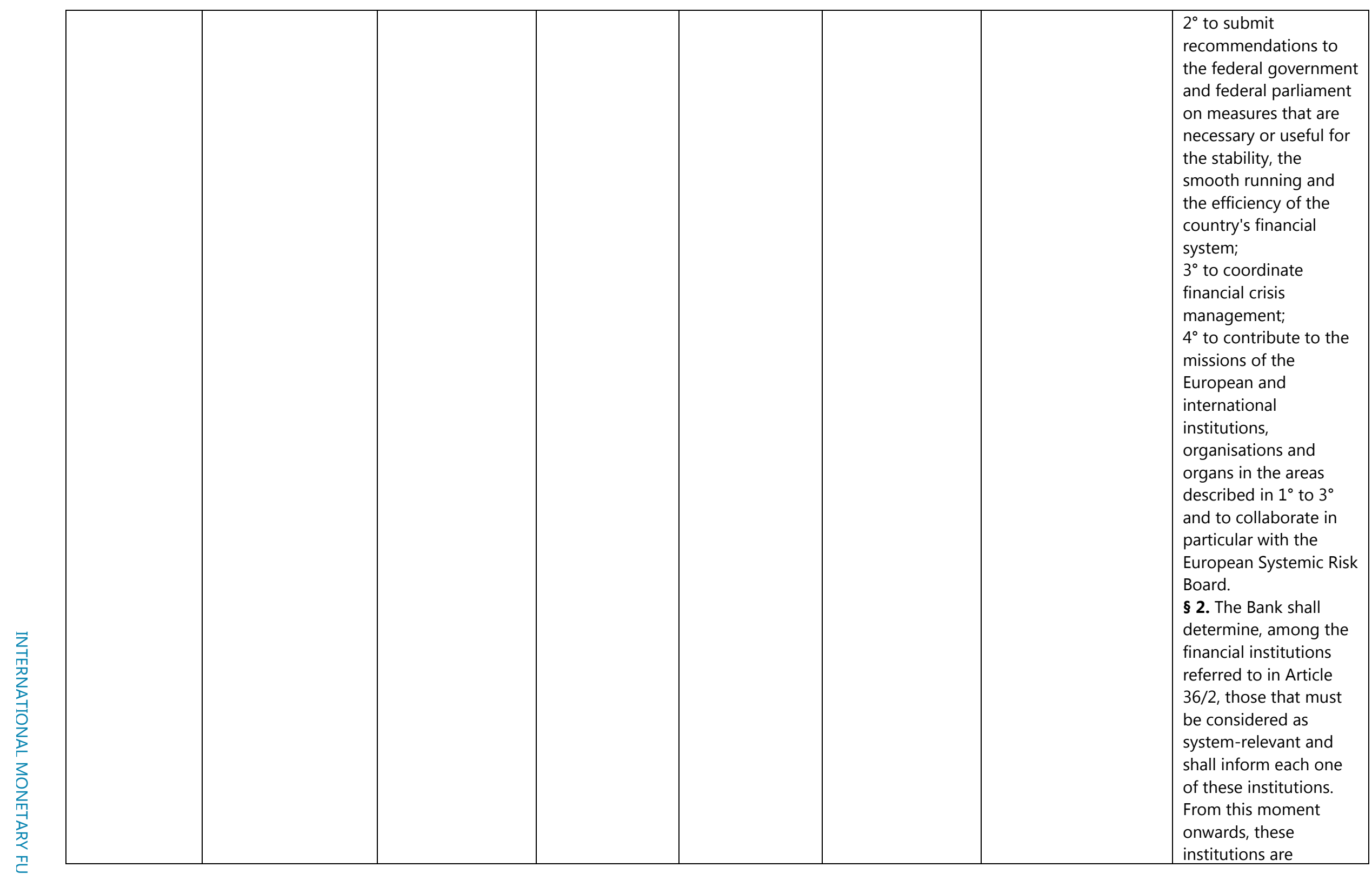




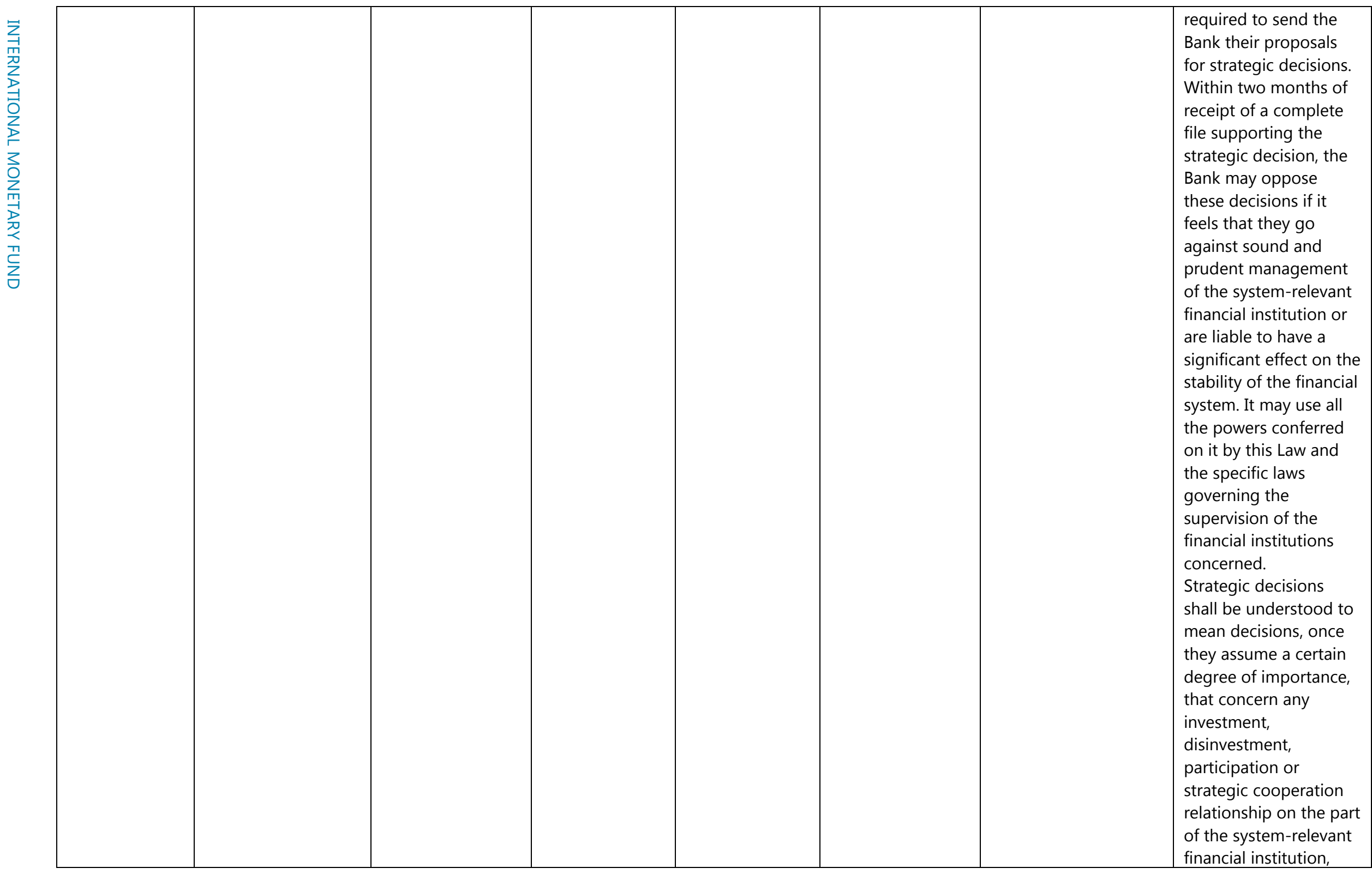




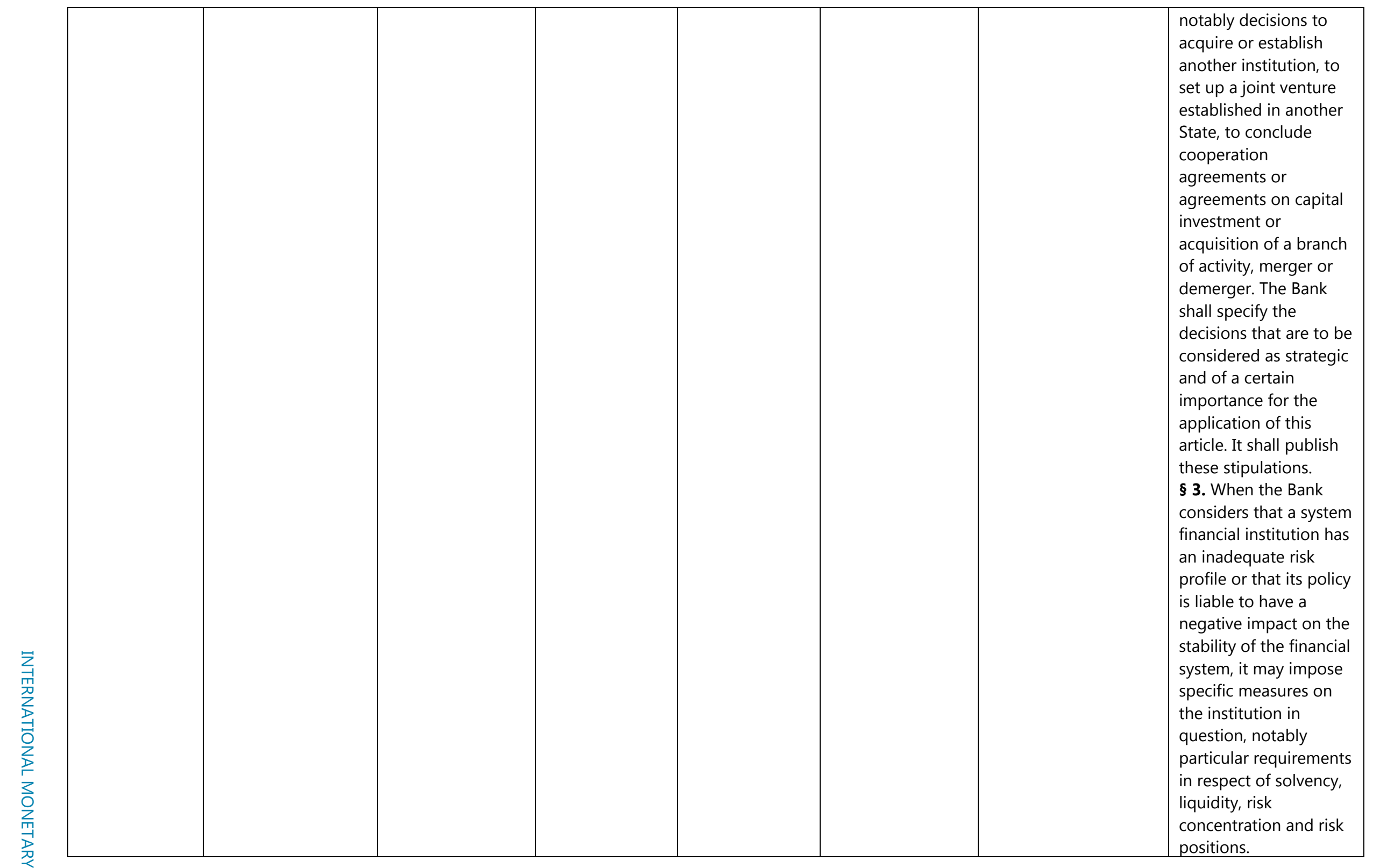




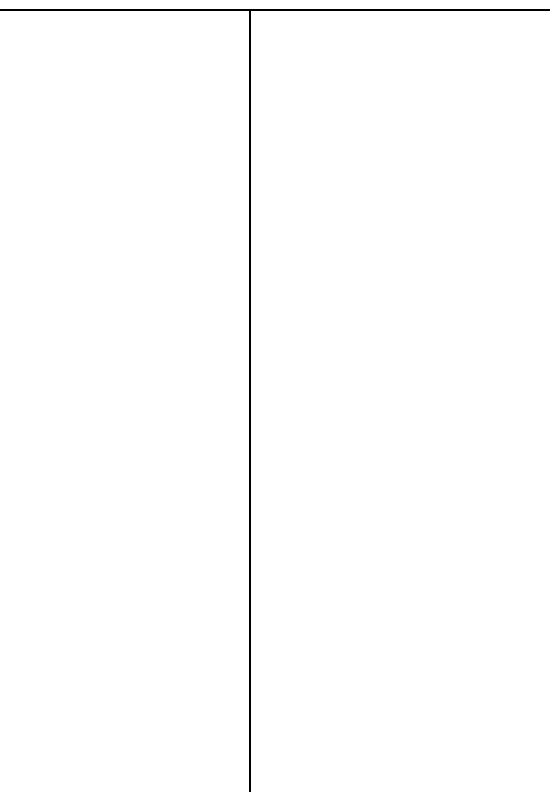

§ 4. To enable the Bank

to exercise the

competences laid

down by the preceding

paragraphs, each

system-relevant

financial institution

shall send it a report

on developments in its

business activities, its

risk position and its

financial situation.

The Bank shall

determine the content

of the information that

must be sent to it as

well as the frequency

and the arrangements

for this reporting. 